\title{
A Review on Tectonic Record of Strain Buildup and Stress Release across the Andean Forearc along the Gulf of Guayaquil-Tumbes Basin (GGTB) near Ecuador-Peru Border
}

\author{
Jacques Bourgois ${ }^{1,2}$ \\ ${ }^{1}$ Université Pierre et Marie Curie (UPMC), Université Paris 06, Unité Mixte de Recherche (UMR) 7193, \\ Institut des Sciences de la Terre Paris (iSTeP), Paris, France \\ ${ }^{2}$ Centre National de la Recherche Scientifique (CNRS), UMR 7193, iSTeP, Paris, France \\ Email: jacques.bourgois@upmc.fr
}

Received January 16, 2013; revised February 22, 2013; accepted March 19, 2013

Copyright (C) 2013 Jacques Bourgois. This is an open access article distributed under the Creative Commons Attribution License, which permits unrestricted use, distribution, and reproduction in any medium, provided the original work is properly cited.

\begin{abstract}
Gravimetric and geologic data show that the reactivation of the Neogene Interandean depression and/or the $\sim 75-65 \mathrm{Ma}$ ophiolite suture into the modern dynamic of the Andes controlled the Gulf of Guayaquil Tumbes basin (GGTB) location and evolution during the past $1.8-1.6 \mathrm{Myr}$ at least. Depending on whether the remobilization occurred along the interandean depression or the ophiolite suture, the GGTB evolved trough pure or simple shear mechanisms, respectively. Because the GGTB exhibits an along strike tectonic asymmetry associated with a pervasive seismic gap, the simple shear solution is more likely. Tectonic inversion occurred along a mid-crust detachment (the Mid-Crust detachment hereafter) matching the ophiolite suture that accommodates the North Andean Block (NAB) northward drift. The so-called Decoupling Strip located at the shelf slope break accommodated the tensional stress rotation from N-S along the shelf area i.e. NAB-drift induced to $\mathrm{E}-\mathrm{W}$ along the continental margin i.e. subduction-erosion-induced. The landward dipping Woollard detachment system located at the Upper-Lower slope boundary connects the subduction channel at depth, allowing the Upper slope to evolve independently from the Lower slope wedge. The long-term recurrence interval between earthquakes, the strong interplate coupling, and the aseismic creeping deformation acting along the main low-angle detachments i.e. the Woollard and the Mid-Crust detachments may account for the pervasive seismic gap at the GGTB area. Because the subduction channel exhibits no record of significant seismic activity, no evidence exists to establish a link between the GGTB sustained subsidence and a basin-centered asperity. Because the GGTB is a promising site of hydrocarbon resources, to understand processes at the origin of this escape-induced forearc basin has a major economic interest.
\end{abstract}

Keywords: Andean Forearc; Strain Buildup; Stress Release; Gulf of Guayaquil-Tumbes Basin; Ecuador; Peru

\section{Introduction}

On the basis of occurrences of ophiolitic rocks, Andes are subdivided into three segments i.e. northern, central and southern [1], which is well documented in post 1973 research works. The presence of mafic and ultramafic rocks characterizes the northern segment of Colombia and Ecuador Andes and the southern segment of the Patagonia and Fuegian Andes. No ophiolitic rock exists along the central Andes from Peru to the Chile triple junction at $46^{\circ} 09^{\prime} \mathrm{S}$. The passage from the northern to central Andes occurs in an area of a major change in trend of the Andes from NNE (Ecuador) to SSE (Peru).
This complex area (Figure 1) is located along the southern segment of the transcontinental Dolores-Guayaquil megashear [2,3]. The Panama block and the South Caribbean Deformed Belt including the Maracaibo block bound the Northern Andes to the North. The Peru-Chile trench, which bounds the Northern and Central Andes to the west, is the signature of the Nazca plate subduction underneath the South America plate. Seismic activity and volcanism are the main signatures of the $6 \mathrm{~cm} \cdot \mathrm{yr}^{-1} \mathrm{E}-\mathrm{W}$ trending convergence between these two plates. The Carnegie Ridge produced by the passage of the Nazca plate over the Galapagos hotspot is being subducted be- 


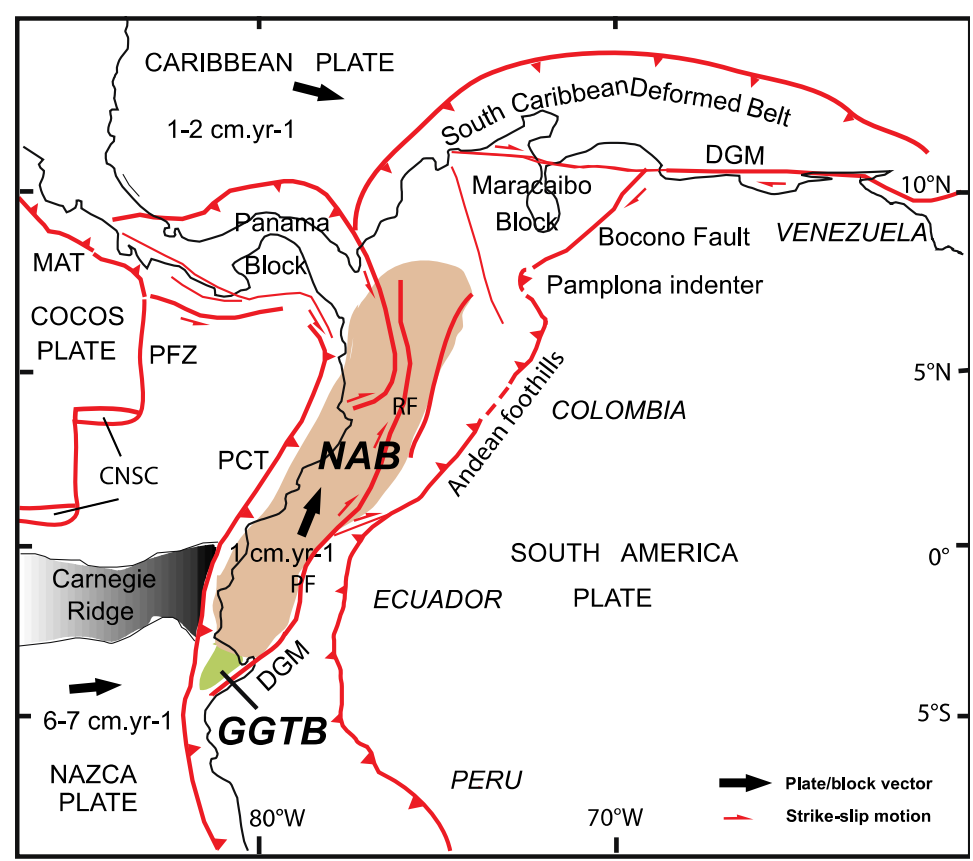

Figure 1. Tectonic and Geodynamic frameworks of the GGTB area located at the southern tip of the NAB [modified from 14]. Average velocity vectors (bold arrows) are from [5,27]. The NAB southeastern boundary includes the Romeral fault (Colombia) and the Pallatanga fault (Ecuador) the later being a segment of the so-called transcontinental Dolores-Guayaquil megashear, which extends from Venezuela to Ecuador. It includes the Bocono fault (Venezuela), the Pamplona indenter [7], the Andean Foothills of the Colombia Andes, which branches southward to the Pallatanga fault. CNSC-Cocos-Nazca spreading center; DGM-Dolores-Guayaquil megashear; GGTB-Gulf of Guayaquil-Tumbes basin; MAT-Middle America trench; NABNorth Andean block; PCT-Peru Chile trench; PF-Pallatanga fault; PFZ-Panama Fracture Zone; RF-Romeral fault.

neath the Ecuador Andes [4]. The subduction of the Carnegie ridge and related higher coupling at plate interface resulted in the northward "escape" of the NAB [2,5]. The northward drift of the NAB was proposed [4] as the main driving mechanism controlling the development of the GGTB for the past 1.8 - 1.6 Myr.

The present research is aimed to identify the tectonic features of the Gulf of Guayaquil-Tumbes segment able to maintain the forearc tensional stress steady during the past 1.8 - 1.6 Myr, trending E-W and N-S along the continental margin and the shelf, respectively. Three major tectonic features, which role was underestimated so far helped to maintain the forearc tensional stress stable. From west to east, it includes: 1) the Woollard detachment system at the Upper-Lower slope boundary connecting the subduction channel at depth that controls the tectonic evolution of the continental margin through time; 2) the Decoupling Strip located along the shelf slope break, which accommodates the tensional stress rotation; and 3) the Mid-Crust detachment, which characterizes the Gulf of Guayaquil-Tumbes basin (GGTB hereafter) basement at depth.

The Ecuador-Peru seismic gap [6] and the Peru flatslab extents are discussed. We address two related questions regarding the state of stress along the southern Ecuador forearc, and the location of the GGTB controlled by inherited tectonics such as the ophiolite obduction and accretion during the Upper Cretaceous times. The mechanical coupling variations along the subduction mega thrust associated to tectonic inheritance have controlled the GGTB location at the southern end of the ophiolite Andes.

We suggest that tectonic escape systems, and the trench ward prolongation of related transcurrent systems such as the Dolores-Guayaquil megashear, are highly sensitive to local margin architecture and regional plate coupling variations, and that these variations are key factors in controlling sustained subsidence and location.

\section{Kinematic and Tectonic Framework}

The Dolores-Guayaquil megashear, which bounds the North Andean block (NAB hereafter) to the east, is a major right lateral transcontinental fault system [2]. It extends from the Pacific coastal area (Ecuador) to the Atlantic Ocean (Venezuela).

Evidences have shown $[3,8,9]$ that oceanic crust emplacement (Figure 2) along Colombia Andes occurred through accretion (Western Cordillera), and obduction (Central Cordillera) during Upper Cretaceous-Lower Tertiary time. At two different sites i.e. at the latitude of Medellin $\left(\sim 6^{\circ} \mathrm{N}\right)$, and Popayan $\left(\sim 2^{\circ} 25^{\prime} \mathrm{N}\right)$ the Central Cordillera exhibits eastward-transported tectonic slices of ophiolite bodies resting above continental crust. 


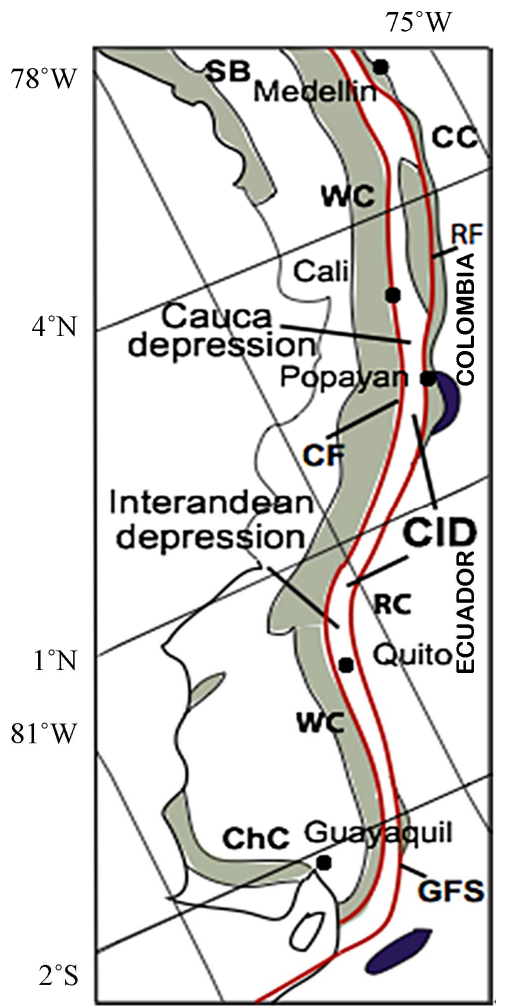

Figure 2. Northern Ophiolite Andes, Cretaceous ophiolite (dark green). The Cauca (Colombia) and the Interandean (Ecuador) depressions [16], the so-called Cauca-Interandean depression separates the Cretaceous ophiolite (Western Cordillera) from the continental basement (Central Cordillera and Real Cordillera) following the $\sim 75$ - 65 Ma ophiolite suture. Obducted Cretaceous oceanic rock is locally known east of the Cauca-Interandean depression [3]. Upper Jurassic-Lower Cretaceous ophiolite (dark blue) exists east of the Cauca-Interandean depression [60]. CF-Cauca fault; ChC-Chongon-Collonche Sierra; CID-Cauca-Interandean depression; CC-Central Cordillera (Colombia); GFSGiron fault system; RC-Real Cordillera (Ecuador); RFRomeral fault; SB-Serrania de Baudo; WC-Western Cordillera.

Subsequently, Upper Cretaceous ophiolite emplacement along Ecuador Andes has been proposed resulting from coeval tectonic events [10]. Indeed, abundant evidences (Figure 3) exist documenting that the Upper Cretaceous Andean ophiolite and associated oceanic plateau fragments of Colombia extends to the south along the Ecuador Andes [10-13].

Both Colombia and Ecuador exhibit a major N-S trending morphotectonic depression bounding the Cretaceous ophiolite to the west from the South America continental basement to the east [14]. It includes the Rio Cauca depression (Colombia) that connects southward to the so-called Interandean depression (Ecuador) to form the Cauca-Interandean depression (Figure 2). This major morphologic feature that separates the Western cordillera (Colombia and Ecuador) from the Central cordillera (Co-

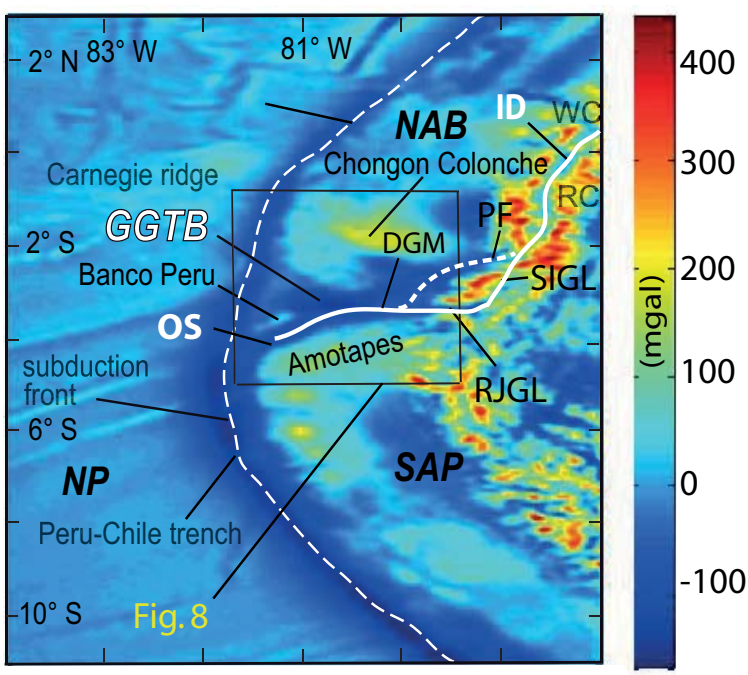

Figure 3. Free-air gravity anomaly map of the Ecuador and northern Peru Andes including the GGTB area [34]; data at http://topex.ucsd.edu/cgi-bin/get_data.cgi]. A contrasting gravity low (thick white line) follows the Interandean depression (ID) and the trace of the ophiolite suture (OS). Note that Santa Isabel and the Rio Jubones gravity lows connect outboard to the gravity low underlying the GGTB. DGMDolores-Guayaquil megashear; ID-Interandean depression; GGTB-Gulf of Guayaquil-Tumbes basin; NAB-North Andean block; NP-Nazca plate; OS-Ophiolite suture; PF-Pallatanga fault; RJGL-Rio Jubones gravity low; SAP-South America plate; SIGL-Santa Isabel gravity low. Location of Figure 8 is shown. Longitude exaggeration $=\sim 2$.

lombia) and the Real cordillera (Ecuador) is controlled by deep-seated faults. The $\sim 75-65$ Ma ophiolite suture and the Neogene Cauca Interandean depression that follow the same restricted strip from northern Colombia to southern Ecuador are closely related one to the other, they define a main tectonic element of the northern ophiolite Andes, the so-called first-order "ophiolite suture/ Cauca Interandean depression" tectonic feature. As to the north, a pervasive negative free-air gravimetric anomaly (Figure 3) underlines the Interandean depression, separating the strong positive anomaly signature of the two main morphotectonic elements of Ecuador Andes, the Western and Real cordilleras.

\section{Geological Framework}

The northern edge (Ecuador) of the Gulf of Guayaquil (Figure 4) exhibits the Cretaceous ophiolite basement cropping out extensively along the E-W trending Chongon-Colonche Sierra. To the South, continental metamorphic basement of Paleozoic age characterizes the northern Peru forearc from the Amotapes massif to within the coastal area, the shelf area and the continental margin [15]. Accretion and obduction of oceanic terranes against the South American continental basement occurred $~ 75$ $65 \mathrm{Ma}$ ago $[3,10,14]$. Paleocene to Eocene sediment, 


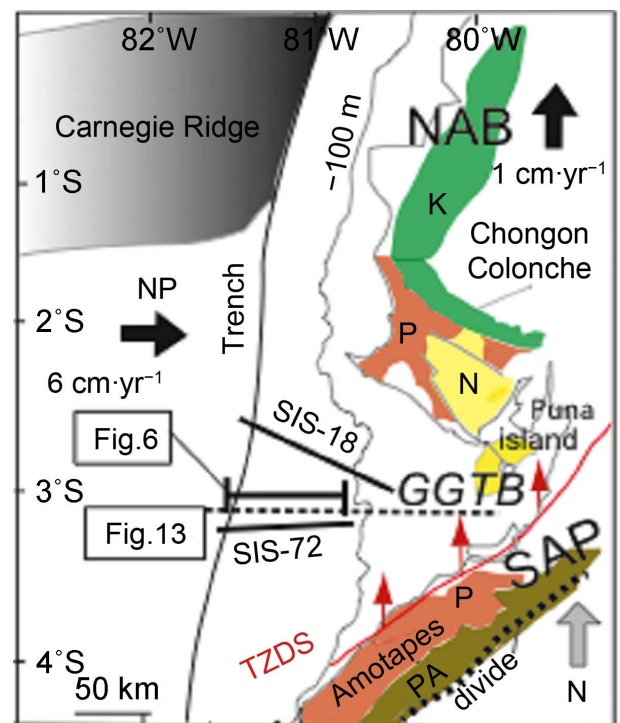

Figure 4. Geologic framework of southern Ecuador and northern Peru. The southern boundary of NAB i.e. the Tumbes-Zorritos Detachment System trends NNE-SSW paralleling the northern Peru coastal line and the Amotapes massif divide. GGTB-Gulf of Guayaquil-Tumbes basin; K-Cretaceous ophiolite; N-Neogene sediment; NAB-North Andean block; NP: Nazca plate; P-Paleogene sediment; PA-Paleozoic continental basement rock; TZDS-Tumbes-Zorritos detachment system. Thick black line-seismic profiles SIS-18 and SIS-72 shot during the SISTEUR cruise [20]; line with red arrows-detachment. Location of Figures 6 and 13 is shown.

which includes the hydrocarbon bearing Ancon (Ecuador) and Talara (Peru) Formations [18] with similar facies and age unconformably overlies oceanic (Ecuador) and continental (Peru) basements. Subsequently, several kilometers of Oligocene to Quaternary Sediment accumulated along the Progreso (Ecuador) and Gulf of Guayaquil (Ecuador)-Tumbes (Peru) basin [19].

The main geologic and tectonic features of the GGTB (Figure 5) were identified on the basis of industrial multichannel seismic reflection profiles and well data $[4$, 23,24]. The Pliocene series show no significant variations in thickness throughout the GGTB area suggesting that no significant tectonic deformation occurred from 5.2 to $1.8-1.6 \mathrm{Ma}$, in association with a widespread and moderate subsidence. The Esperanza, Tenguel, Jambeli, and Tumbes-Zorritos sub-basins were identified as major Quaternary depocenters with high subsidence rates. More than $3-5 \mathrm{~km}$ of clastic sediment accumulated at these four restricted sub-basins during the past 1.8 - 1.6 Myr.

The GGTB has evolved in the tectonic wake of the northward-migrating NAB [4] in a way similar to that of a pull-apart basin $[25,26]$. Indeed, the analysis of Industrial seismic lines has documented that the $\sim 1 \mathrm{~cm} \cdot \mathrm{yr}^{-1}$ northward migration rate of the NAB $[2,5,27]$ was at the origin of trench-parallel tensional stress that has con- trolled subsidence and GGTB formation.

\section{Shelf Area}

Major detachments and faults that include the PosorjaJambeli, the Tumbes-Zorritos detachment systems, and the Inner Domito-Banco Peru fault system clockwise (Figure 5) are the tectonic boundaries of the GGTB at Present. These boundaries and tectonic evolution have been described in great details $[4,23,28,29]$. Only the main points are reminded here. The Posorja-Jambeli detachment system, which controlled the evolution of the GGTB northern edge, exhibits tectonic activity from the end of the Pliocene to the Upper Pleistocene time. The northern GGTB boundary shows no active deformation since the Late Pleistocene. The northeast trending TumbesZorritos detachment system, which parallels the coastline of northwestern Peru, controlled the GGTB southern edge evolution for the past $1.8-1.6$ Myr. Although the detachment trace is obscured to the east i.e. along the Tumbes-Machala coastal area it is inferred that the Tumbes-Zorritos detachment system connects the southward prolongation of the Dolores-Guayaquil megashear, as first suggested by [30]. Subsequently, similar inference was suggested [2]. To the west, no evidence exists for the Tumbes-Zorritos detachment system to extend west of Banco Peru [23]. As opposed to the GGTB northern edge the Tumbes-Zorritos detachment system exhibits a pervasive tectonic activity at Present including strong signature along trace at seafloor. The northern and the southern GGTB boundaries connect westward to the N-S trending Inner Domito-Banco Peru fault system. This high dipping fault system roughly located at the continental shelf break exhibits tectonic features such as flower structures documenting both transtensional and transpressive motion along trend.

\section{Continental Margin}

Along Southern Ecuador [20] and Northern Peru [17,2123,31] the Lower and the Upper slopes of the continental margin evolved controlled by normal faults and detachments. Off Northern Peru, these N-S trending tectonic features parallel the trench axis extending upslope to the continental shelf break area. It includes $[4,23,24]$ the Talara detachment (Figure 5) extending from $4^{\circ}$ to $4^{\circ} 43^{\prime} \mathrm{S}$. Along the GGTB segment, the continental margin west of the Outer Domito-Banco Peru fault system exhibits $\sim \mathrm{N}-\mathrm{S}$ trending normal faults documented by deep multichannel seismic reflection. It includes the E-W trending SIS-18, SIS-20 and SIS-72 profiles (Figures 4 and 5 for location), which extend from the subduction front to the shelf-slope break. These profiles [20,32] exhibit (Figure 6) a small frontal prism, the overriding plate basement and slope sediment, and a well-defined 


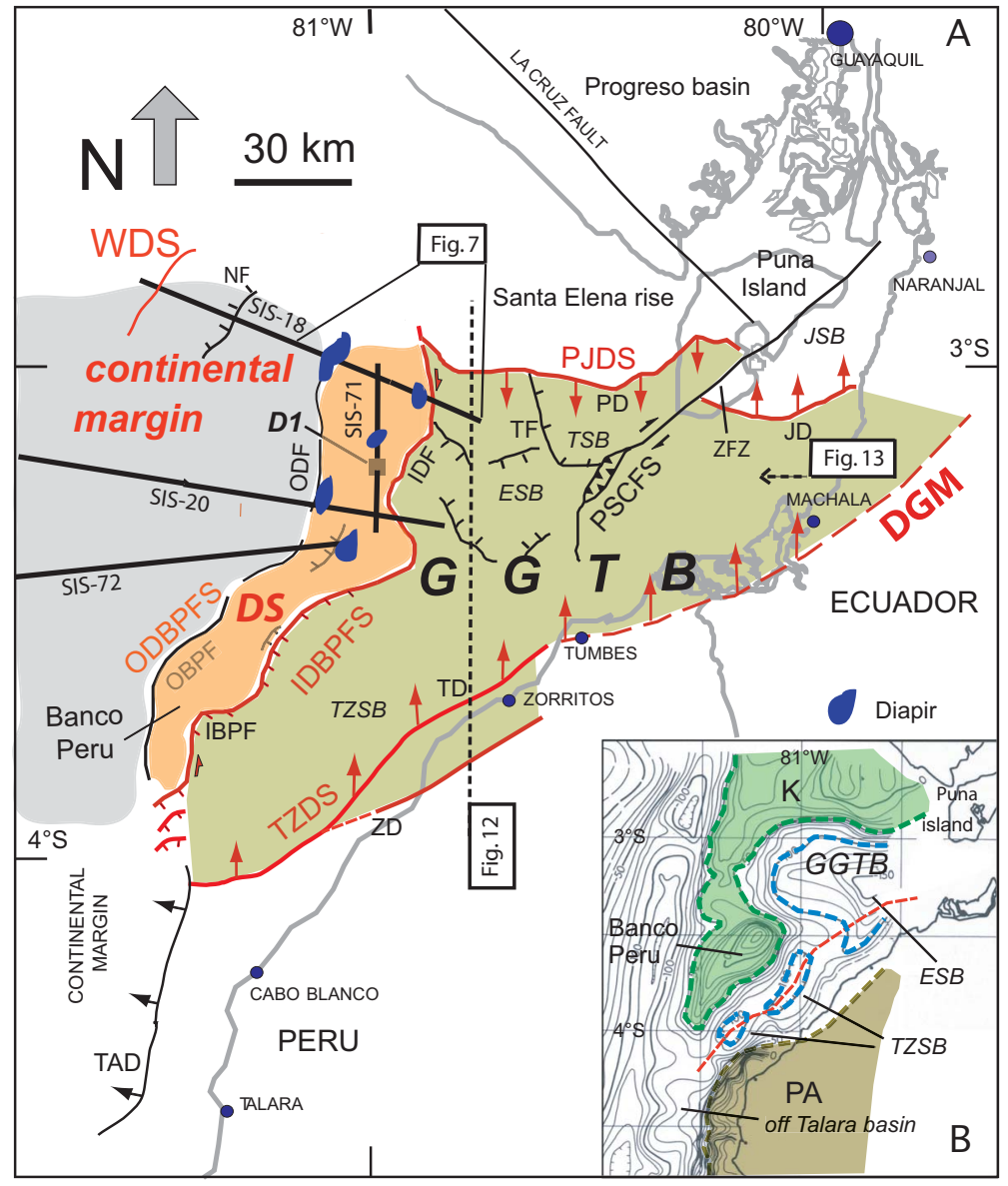

Figure 5. GGTB area showing main tectonic features (thick red line) at boundaries; modified and supplemented from [4]. Lower right box: Free-air gravity anomaly map (10 mgal contours) of the GGTB area after [32]. Contrasting gravity high underlies Banco Peru. Red dash line connects major gravity lows i.e. major depocenters located along the narrow strip bounding at depth the Cretaceous ophiolite complex (K) to the north from the Paleozoic metamorphic rock (PA) of the South America continental basement. D1-Domito 1 industrial well; ESB-Esperanza sub-basin; GGTB-Gulf of Guayaquil-Tumbes basin; IBPF-Inner Banco Peru fault; IDBPFS-Inner Domito-Banco Peru fault system; IDF-Inner Domito fault; JD-Jambeli detachment; JSB-Jambeli sub-basin; K-Cretaceous ophiolite; N-Neogene sediment; OBPF-Outer Banco Peru fault; ODBPFSOuter Domito-Banco Peru fault system; ODF-Outer Domito fault; PA-Paleozoic continental basement rock; PD-Posorja detachment; PJDS-Posorja-Jambeli detachment system; PSCFS-Puna-Santa Clara fault system; TAD-Talara detachment; TD-Tumbes detachment; TF-Tenguel fault; TSB-Tenguel sub-basin; TZDS-Tumbes-Zorritos detachment system; TZSBTumbes-Zorritos sub-basin; ZD-Zorritos detachment; ZFZ-Zambapala fault zone. Thick black line-seismic profiles SIS-18, SIS-20, SIS-71, and SIS-72 [20]; line with barb-normal fault; line with lateral arrow-strike-slip fault and transform; line with arrows-detachment. Location of Figures 7, 12 and 13 is shown.

subduction channel extending $\sim 90 \mathrm{~km}$ landward from the trench axis. Physical properties variations of underthrust sediments along the subduction channel indicate sediment compaction and fluid drainage within the $5-9 \mathrm{~km}$ landward from the trench axis. Undrained conditions characterize the segment located between 5 and $25 \mathrm{~km}$ landward from the trench axis. Inward, sudden porosity decrease associated with a strong velocity increase along the subduction channel document higher coupling at plate interface. Condition for earthquake generation places the updip limit at $16-30 \mathrm{~km}$ landward from the trench axis. At this site, fluid release induces hydrofracturation, which facilitates subduction erosion and increase cou- pling at plate interface.

Along profile SIS-18 (Figure 6), N-S trending normal faulting, which characterizes the continental slope extends from 16 to $62 \mathrm{~km}$ landward from the trench axis. The tensional stress regime of the continental margin was long before considered as the response to tectonic erosion acting along the subduction channel [33], including off northern Peru [21,22,31]. It is assumed the E-W trending tensional stress regime as documenting the distribution of subduction erosion working at depth at the base of the overriding plate. Because of existence of high coupling (Figure 6) the subduction channel is potentially seismogenic between 16 and $62 \mathrm{~km}$ from the trench axis. 


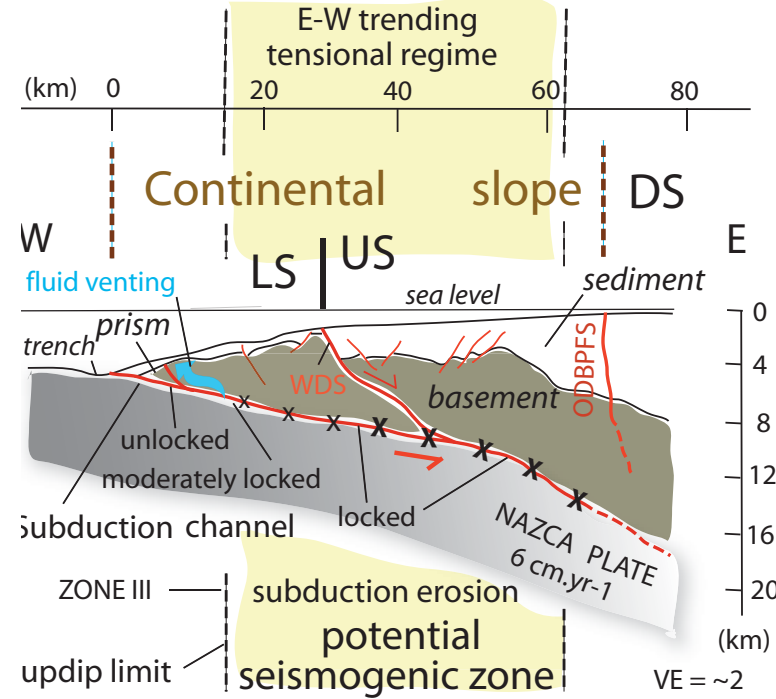

Figure 6. Continental margin west of the GGTB area. Basic data are from seismic profile SIS-18 [20]. An extensive N-S trending normal-fault network documents a pervasive $\mathrm{E}-\mathrm{W}$ trending tensional tectonic regime. A major landward dipping detachment, the Woollard detachment system, which bounds the Upper Slope from the Lower Slope connects downward to the subduction channel. It is a potential decoupling zone between the Upper Slope and Lower Slope. The so-called ZONE III [32] coincides with the updip limit at depth. At this site, release of over-pressured fluid occurs along the subduction channel. DS-Decoupling Strip (Figure 5); LS-Lower slope; ODBPFS-Outer Domito-Banco Peru fault system; US-Upper slope; VE-vertical exaggeration; WDS-Woollard detachment system. Location on Figure 4.

The corresponding E-W trending tensional stress, which characterizes the continental margin, extends upslope to the Outer Domito-Banco Peru fault system.

The seismic profile SIS-18 exhibits a major landward dipping normal fault system bounding the Upper slope from the Middle slope area at about $29 \mathrm{~km}$ from the trench axis. This active fault system, which dips less than $20^{\circ}$ landward developed as a growth fault cutting across the continental margin basement down to the subduction channel. To the east, the thick sediment accumulation overlying the continental margin basement exhibits a pervasive normal faulting network trending parallel to the trench axis. The seaward footwall of the detachment system being considered fixed, the hanging wall moved $\sim 3 \mathrm{~km}$ eastward. We have named this major fault the "Woollard detachment system" (see acknowledgments).

\section{Decoupling Strip at the Shelf Slope Break}

The eastern end of profiles SIS-18, SIS-20, and SIS-72 [20] crosscut (Figure 5) the high-dipping Inner and Outer Domito-Banco Peru fault systems [4]. These fault systems located at about $10 \mathrm{~km}$ apart develop in 150 to 500 $\mathrm{m}$ water depth roughly following the shelf-slope break, seaward the GGTB area. The Inner and Outer DomitoBanco Peru fault systems bound a N-S trending seafloor strip, the Decoupling Strip hereafter, extending from the latitude of the Posorja detachment to the north to Banco Peru southward. The Decoupling Strip bounds the GGTB to the east from the continental margin extending seaward to the trench axis.

Along profile SIS-18 (Figure 7), the Decoupling Strip

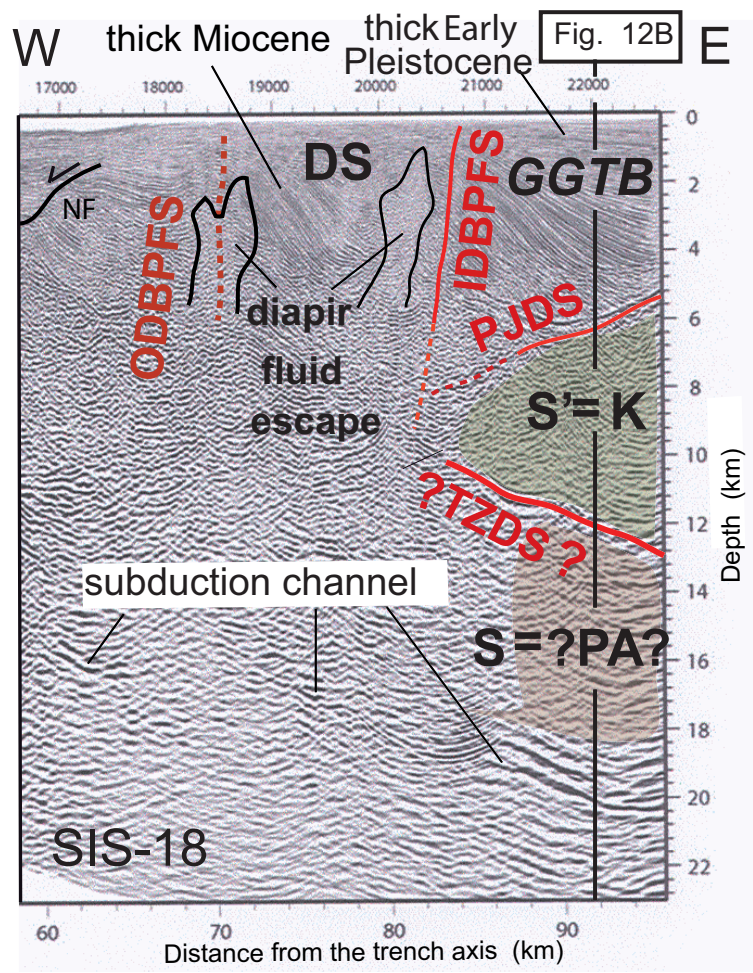

Figure 7. The Decoupling Strip, which exhibits extensive diapir structures bounds two different domains: the continental margin characterized by $\mathrm{N}-\mathrm{S}$ trending normal faults to the west, and the GGTB sediment accumulation resting above the Cretaceous ophiolite basement to the east. East of profile, the major structural truncation bounding the sediment from the basement is the southward prolongation of the Posorja Jambeli detachment system at depth. At 12 - 13 km depth a group of strong reflections bound the chaotic and contorted reflection-free seismic configuration of the Cretaceous ophiolite basement from a basal unit called $S$ unit [20] characterized by sub-parallel strong reflections. The basal unit is tentatively assigned to the Paleozoic metamorphic basement (see text for more detail). If so, the strong reflections at the base of the ophiolite basement are the signature of the obduction megathrust. Also the strong reflections branch upward to the Tumbes-Zorritos detachment system. See Figure 12B and text for more detail. DSDecoupling Strip at the shelf-slope break area; GGTB-Gulf of Guayaquil-Tumbes basin; IDBPFS-Inner Domito-Banco Peru fault system; K-Cretaceous ophiolite basement; NFNormal fault; ODBPFS-Outer Domito-Banco Peru fault system; PA-Paleozoic metamorphic basement; PJDS-Posorja-Jambeli detachment system; TZDS-Tumbes-Zorrito detachment system. Location on Figure 5. 
is associated with major diapir structures [20,24]. To the south, the Decoupling Strip includes the shallow depth flat-toped bathymetric high of Banco Peru, which exhibits no clear seismic reflection [4]. As a consequence, no direct correlation is possible between the fairly well constrained GGTB stratigraphy $[4,19,24]$ and the seismic facies signature of sediment that accumulated west of the Inner Domito-Banco Peru fault system including not only the Decoupling Strip but also the continental margin west of the Outer Domito-Banco Peru fault system. The Domito 1 industrial well (D1, Figure 5) located along the Decoupling Strip documents that the main pulse of sediment accumulation along this area occurred during the Miocene-Early Pliocene time [19,24]. This pulse is 2 to 5 Myr older than at GGTB depocenters as documented at Esperanza and Tenguel sub-basins. Moreover, the Pleistocene sediment, which accumulated at Domito 1, is three to four times less thick than east of the Inner DomitoBanco Peru fault system at few kilometers apart. The Inner Domito-Banco Peru fault system is a major and sharp boundary, which exhibits significant tectonic and paleogeographic signatures.

The shale diapir structures characterizing the Decoupling Strip are deep-rooted into a $6-10 \mathrm{~km}$ thick-accumulation of sediment i.e. far below the base of the Late Pleistocene sediment. The diapir material originated from under-compacted sediment located underneath the thick Miocene to Early Pliocene sediment. These diapir structures associated with upward massive extrusion, reaching the seafloor or not, are located along the core axis of major anticlines. The Decoupling Strip exhibits shortening tectonic features associated with fluid venting drained along the diapir structures. Locally, 2 to $3 \mathrm{~km} \sim \mathrm{E}-\mathrm{W}$ trending shortening occurred along the Decoupling Strip. Because thin accumulation of slope sediment unconformably overlies some of diapir structures it is assumed that the shortening recorded along the Decoupling Strip occurred coevally with the GGTB evolution, at least during the past 1.8 - 1.6 Myr. Given the range of sediment thickness unconformably overlying the diapir structures we suspect that non-linear tectonic deformation occurred along the Decoupling Strip, both in space and time.

\section{Free Air Gravity Anomalies}

A prominent negative free-air gravity anomaly characterizing the Ecuador Andes [34] extends from northern Ecuador to the Gulf of Guayaquil area (Figure 3). It forms together with the gravity low at the boundary between the Western and Central cordilleras of Colombia the Main Andean gravity low underlying the Cauca-Interandean depression (Figure 2). Along the Ecuador Andes, this first order gravity feature is located along the
Interandean depression, which separates the Western cordillera from the Real cordillera. Because the ophiolite suture is roughly following the Interandean depression, the main Andean gravity low is also the signature at the boundary between the Cretaceous ophiolite and the South America continental basement. The Main Andean gravity low, following the Interandean depression exhibits a major westward bend at about $3^{\circ} \mathrm{S}$ Latitude. The change in trend from north south to east west occurs along the area that connects the Santa Isabel basin to the Rio Jubones fault, both tectonic features being associated with a prominent negative anomaly (Figures 3 and 8). The South America metamorphic basement characterizing the N-S trending Real cordillera follows the bend of the Interandean depression extending westward to the Amotapes massif (northern Peru). The gravity high associated with the Amotapes massif trends $\sim$ N45E paralleling the northeast trending gravity low underlying the Tumbes-Zorritos and Esperanza sub-basins (thick white line, Figures 3 and $\mathbf{8}$ ).

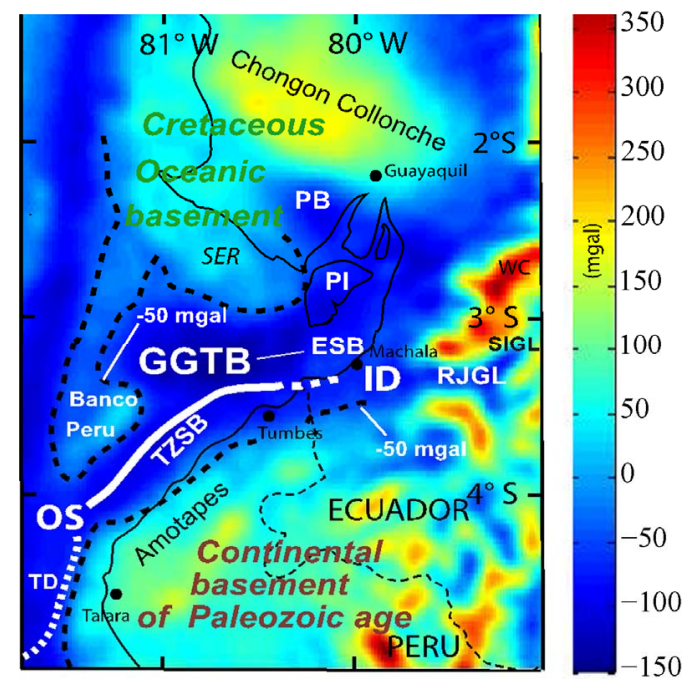

Figure 8. Free-air gravity anomaly map of the GGTB area [34], data at http://topex.ucsd.edu/cgi-bin/get_data.cgi]. The Banco Peru $\left(3^{\circ} 30\right.$ 'S $\left.-81^{\circ} 15^{\prime} \mathrm{W}\right)$ gravity high connects the Santa Elena rise and the coastal area to the north documenting the southward extension of the Cretaceous oceanic basement to about $3^{\circ} 50$ 'S. A major gravity low (thick white line) underlines sediment depocenters including the Tumbes-Zorritos and the Esperanza sub-basins. This gravity low connects eastward the Rio Jubones and the Santa Isabel gravity lows. Inference allows locating the Upper Cretaceous-Paleocene ophiolite suture and/or the Interandean depression along the major GGTB gravity low i.e. the thick white line at depth. See text for more details. ID-Interandean depression; ESB-Esperanza sub-basin; GGTB-Gulf of Guayaquil-Tumbes basin; OS-ophiolite suture; PB-Progresso basin; PI-Puna Island; RJGL-Rio Jubones gravity low; SER-Santa Elena rise; SIGL-Santa Isabel gravity low; TD-Talara detachment (thick white dash line); TZSB-TumbesZorritos sub-basin. 
Indeed, free-air gravity anomalies of the GGTB area (Figure 8) document the location of depocenters and extension including the southwestward prolongation of the Tumbes-Zorritos sub-basin to about $4^{\circ} \mathrm{S}$ Latitude. South of $4^{\circ} \mathrm{S}$, a prominent steep positive anomaly gradient following the N-S trending narrow shelf off northern Peru is the signature of the seaward prolongation of the dense Paleozoic rock of the Amotapes massif [30]. The N-S trending Talara fault, which is a seaward dipping major detachment [23], follows this prominent gravity anomaly. At $3^{\circ} 30^{\prime} \mathrm{S}-81^{\circ} 15^{\prime} \mathrm{W}$ a major contrasting gravity high underlies the shallow water (less than $200 \mathrm{~m}$ water depth) flat-topped Banco Peru (Figures 5 and 8) located 40 - $50 \mathrm{~km}$ seaward from the Peru shelf. This gravity anomaly exhibits no southward connection with the prominent gravity signature bounding the seaward prolongation of the Amotapes Paleozoic rock. Conversely, the gravity anomaly related to Banco Peru connects to the north the gravity high, which characterizes the mafic and ultra-mafic basement of the Santa Elena rise and the Chongon-Colonche sierra. In agreement with Shepherd and Moberly [30] it is inferred that the Upper Cretaceous oceanic basement extends southward to Banco Peru.

At a regional scale, the gravity anomalies allow inferring that the Santa Isabel depression i.e. a segment of the Interandean depression located at $3^{\circ}-3^{\circ} 20^{\prime} \mathrm{S}$ connects with the $\sim \mathrm{E}-\mathrm{W}$ trending gravity low underlying the Rio
Jubones fault. In turn, the Rio Jubones gravity low connects westward with the gravity low underlying the Tumbes-Zorritos and Esperanza sub-basins. Based on present study it is inferred that the Interandean depression, together with the associated Cretaceous ophiolite suture extend beneath the GGTB, following the Tumbes-Zorritos and Esperanza sub-basin gravity lows. As documented along the Colombia and Ecuador Andes [3,9,11], a negative gravity anomaly underlies the GGTB depocenters that is roughly bounding the Cretaceous ophiolite from the South America metamorphic basement.

The major transcontinental Dolores-Guayaquil megashear (Figure 1) is commonly proposed to follow the Interandean depression that matches the proposed active NAB boundary along southern Ecuador Andes. Indeed active faulting [3,14-16] bounds this major morphological depression not only in Ecuador but also along the Cauca depression in Colombia (Figure 2). A dramatic example of such faulting is the active Giron fault, a major normal fault [35] bounding the eastern side of the Santa Isabel depression (Figure 9). Because the Santa Isabel gravity low connects westward with the Rio Jubones and the Tumbes-Zorritos gravity lows, it is suggested that the active Giron, Rio Jubones and Tumbes-Zorritos fault systems are good candidates to be traces of the main Dolores-Guayaquil megashear at Present. To the north, the right lateral Pallatanga fault (Figure 8) was proposed

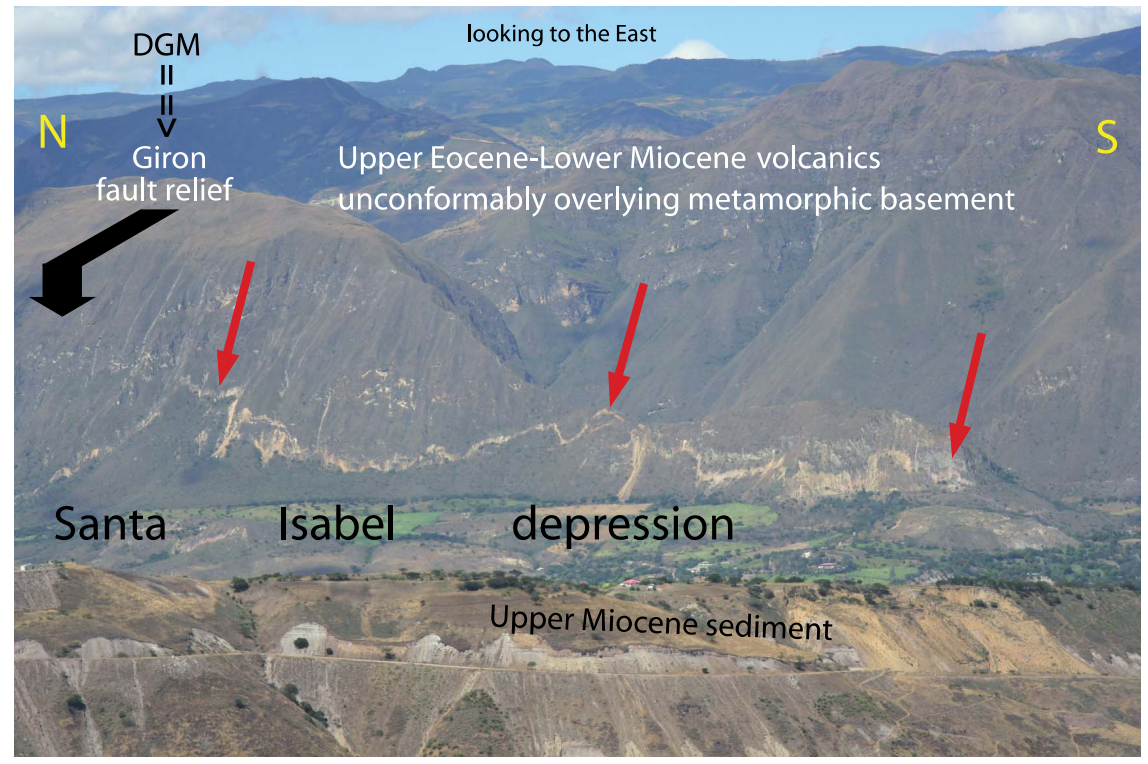

Figure 9. The Santa Isabel depression associated with a major gravity low exemplifies the morphotectonic signature of the Interandean depression as exposed from $2^{\circ} 15^{\prime}$ to $3^{\circ} 20^{\prime} \mathrm{S}$. The Giron fault, which bounds the Santa Isabel depression to the east, is a major fault extending several tens of $\mathrm{km}(\sim 120 \mathrm{~km})$. Locally, the Giron fault is a major normal fault (the thick black arrow shows the footwall). The basement of the Santa Isabel depression i.e. the hanging wall of the fault is down displaced by about $1 \mathrm{~km}$. Red arrow shows the gash left by the last fault displacement along the Giron fault adding 5 - 8 m to the downthrow component. The Giron fault is considered as a segment of the Dolores-Guayaquil megashear. Light brown and white outcrops in the foreground are Upper Miocene sediment infilling the Santa Isabel depression. Thickening of sediment towards the fault documents that the Giron fault evolved as a growth fault since Upper Miocene time. DGM-Dolores-Guayaquil megashear. Location at Figures 2, 3 and 8. 
to be a segment of the transcontinental Dolores-Guayaquil megashear. This proposition makes sense since the active Pallatanga fault follows a prominent gravity low (dash line, Figure 8) connecting southward to the TumbesZorritos and Esperanza sub-basins gravity low. A possible issue would be the Pallantaga fault accommodating the right lateral component of the NAB northward displacement while the Giron fault is accommodating the coeval E-W trending tensional stress.

\section{Earthquake Rupture Zones and Volcanisme}

In Andes a 700 - $800 \mathrm{~km}$ long segment has been identified where no subduction related earthquake has been recorded till today $[6,36,37]$. This segment of the Andes (Figure 10) extends from $1^{\circ} \mathrm{N}$ i.e. north of the Carnegie ridge (Ecuador) to $8^{\circ} \mathrm{S}$ (northern Peru), the GGTB area being located along this specific segment. North of $1^{\circ} \mathrm{N}$, frequent subduction-type thrusting earthquakes $(5<\mathrm{Mw}$ $<7$ ) with $\sim 500 \mathrm{~km}$ maximum rupture length are associated with the Ecuador-Colombia Andean forearc and a $25^{\circ}-30^{\circ}$ slab dip. Subsequently, fault plane solutions

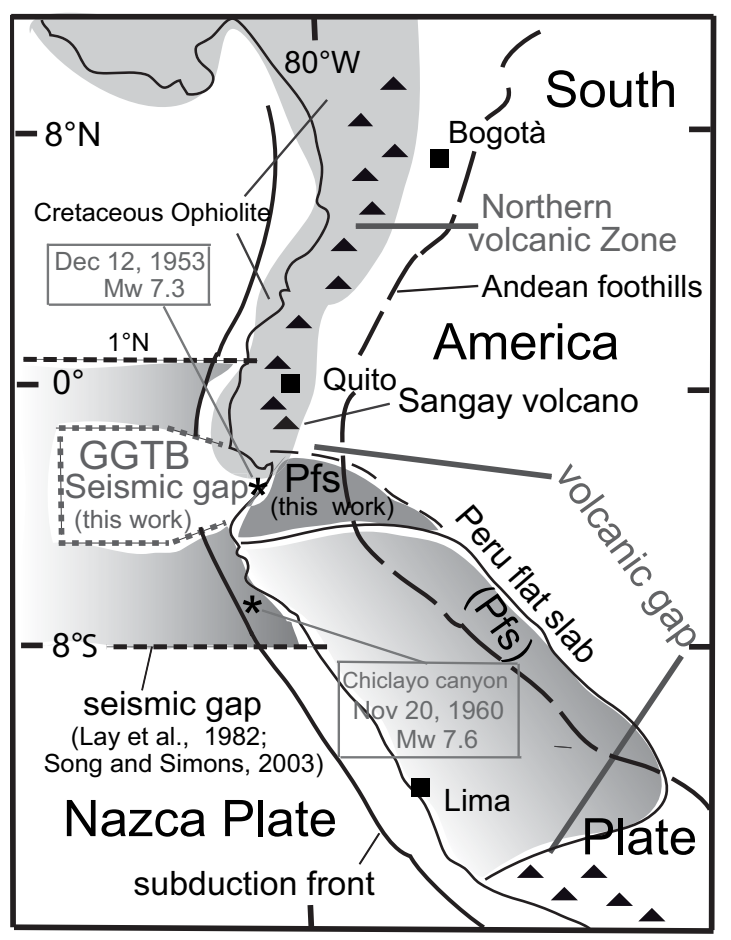

Figure 10. The Peru flat slab (Pfs, dark grey) is proposed (this work) to extend northward to the active Sangay volcano (southern Ecuador, $2^{\circ} \mathrm{S}$ ). The Peru flat slab segment overlapping the 20 - 25 Ma old volcanic gap of the Central Andes extends at depth beneath the GGTB area. The seismic gap proposed to extend from $1^{\circ} \mathrm{N}$ to $8^{\circ} \mathrm{S}[36,51]$ is restricted to the small GGTB segment. See text for more detail. GGTB-Gulf of Guayaquil-Tumbes basin; Pfs-Peru flat slab; black triangle-volcano. obtained from the Harvard CMT catalog associated with hypocenter location [38] documented that the segment exhibiting large earthquakes extends southward to $2^{\circ} \mathrm{S}$ i.e. south of the southern flank of the Carnegie ridge. Indeed a cluster of intermediate-depth seismicity located along the southern flank of the Carnegie ridge defines the southern limit of the Ecuador-Colombia rupture zone that coincides with the northern edge of the GGTB. Also these data allowed proposing a flat slab signature for the Carnegie ridge subduction [39]. Along this specific segment i.e. from $1^{\circ} \mathrm{N}$ to $2^{\circ} \mathrm{S}$ that includes the Carnegie ridge segment, data from a network of 54 seismic stations deployed from December 1994 to May 1995 [40] have evidenced that no flat slab exists in relation with the Carnegie ridge subduction as previously claimed. Along the Ecuador-Colombia Andes the slab is plunging continuously down to a depth of $200 \mathrm{~km}$ with a dip of $25^{\circ}$ $35^{\circ}$ i.e. with no significant variation remaining fairly constant from $3^{\circ} \mathrm{N}$ to $2^{\circ} \mathrm{S}$ Latitude. Also the EcuadorColombia segment exhibits a prominent active volcanism extending southward to the Sangay volcano located at $\sim 2^{\circ}$ S i.e. the Latitude of the GGTB northern edge.

To the south between $8^{\circ}$ and $18^{\circ} \mathrm{S}$ along the Peru subduction zone, great earthquakes occur with maximum rupture length of $150 \mathrm{~km}$ and a flat-dipping slab suggesting greater inter plate coupling than to the north [36]. The Peru slab dip has been documented to be $10^{\circ}-15^{\circ}$ from about $2^{\circ} \mathrm{S}$ to $18^{\circ} \mathrm{S}[38,41-43]$. This Peru Andean segment including the GGTB area exhibits a pervasive volcanic gap for the past $15-30 \mathrm{Myr}$ that is commonly considered as related to the low angle subduction $[42,43]$. The flat slab provides a cold underplate to the overlying Peruvian lithosphere allowing no slab melting. This pervasive along strike situation characterizes not only the central and northern Peru Andes but also southern Ecuador, including the GGTB segment.

Significant seismic activity along the Peru subduction zone allows to question the southern extension of the seismic gap (Figure 10) proposed to extends to $8^{\circ} \mathrm{S}$ [6,36,37]. The seismic activity includes: 1) The moderate magnitude (M 6.75 PAS) subduction earthquake, which occurred the November 20,1960, at the Chiclayo canyon area $\left(6^{\circ} 43^{\prime} \mathrm{N}-80^{\circ} 54^{\prime} \mathrm{W}\right.$, Figure 10) excited an anomalously large tsunami (run up $9 \mathrm{~m}$ at the Peruvian coast). Data modeled by combining the body wave time function and a $130 \mathrm{~s}$ cosine time function representing a longer period component allowed evidencing [44] the tsunami excitation to be not anomalous relative to the measured seismic moment and moment magnitude ( $\mathrm{Mw}$ 7.6). The disparity between tsunami height and surface wave magnitude resulted from underestimation of the earthquake size by conventional magnitude scales due to the long source duration $(110 \mathrm{~s})$. This thrust event was a major subduction earthquake, which occurred $\sim 150 \mathrm{~km}$ north of 
$8^{\circ} \mathrm{N}$; 2) North of the Chiclayo canyon area, it is commonly considered that no major seismic activity is recorded. Even if not clearly related to the subduction, the December 10, $1970(\mathrm{Mw} 7.1)$ event $\left(3^{\circ} 58^{\prime} \mathrm{S}-80^{\circ} 40^{\prime} \mathrm{W}\right.$, $15 \mathrm{~km}$ depth) should be mentioned [US Geological Survey data base [45]; 3) Geomorphic analysis of coastal landforms $[23,28]$ in an area extending from $3^{\circ} 30^{\prime}$ to $7^{\circ} 30^{\prime} \mathrm{S}$ shows that major uplift i.e. $\sim 300 \mathrm{~m}$ occurred through a sequence of major earthquakes with a calculated recurrence of $1250-1437 \mathrm{yr}$ for the past $\sim 25 \mathrm{kyr}$. As at similar situations [46,47], these major events are considered as the signature of the seismogenic activity along the subduction megathrust. The long recurrence interval of earthquake events is likely to explain the seismic gap proposed to characterize this specific segment of the Andean forearc.

To the north, from $3^{\circ} 30^{\prime}$ to $4^{\circ} \mathrm{S}$, seismic activity (Figure 11) occurs along the coastal plain of northern Peru, following the shoreline from Tumbes to Talara (Figure 5). It includes the December 12, 1953, Mw 7.3 earthquake (epicenter at $3^{\circ} 40^{\prime} \mathrm{S}-80^{\circ} 30^{\prime} \mathrm{W}$; Figure 10). No seismic evidence exists for this 1953 event to originate

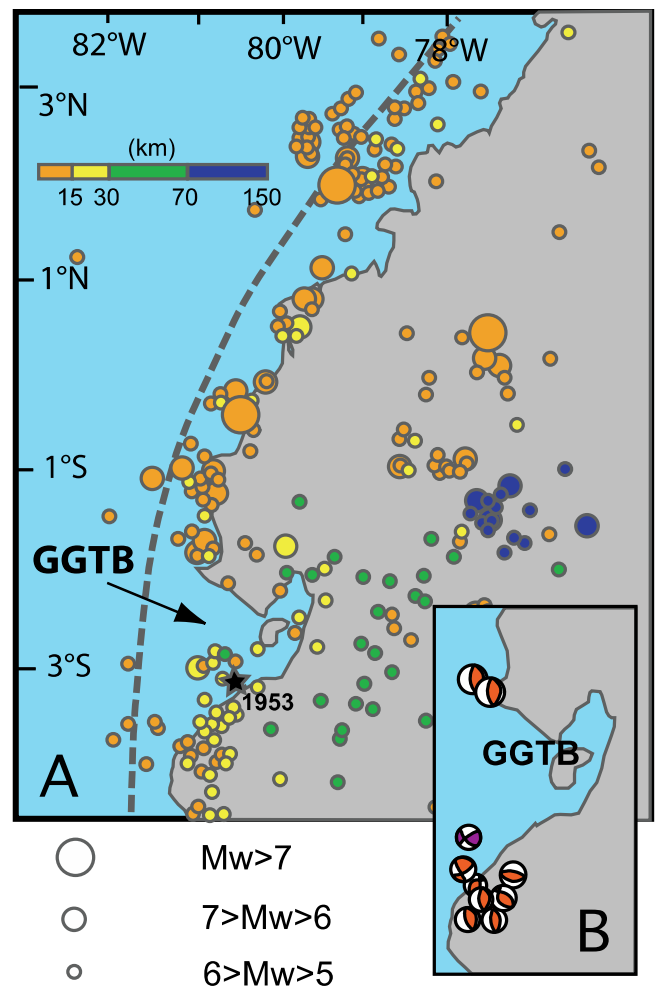

Figure 11. (A) Seismic events location along the Andean segment extending from southern Colombia to northern Peru, data from the USGS-NEIC catalogue, 1973 to Present [38]. Location of the $1953 \mathrm{Mw}$. 7.3 event (black start); (B) Focal mechanisms of seismic events $7>M w>6$ along the GGTB segment, data from the Harvard Centroid Catalogue. Note that a pervasive seismic gap exists along the GGTB segment. from the subduction megathrust or the Tumbes detachment system either. Finally, the segment extending from $1^{\circ} \mathrm{N}$ to $8^{\circ} \mathrm{S}$ exhibits a seismic gap (Figures 10 and 11) but restricted to the GGTB segment extending from $\sim 2^{\circ}$ to $3^{\circ} 30^{\prime} \mathrm{S}$. No direct evidence exists to define whether this gap is a bias originating from the long lasting earthquake recurrence interval or not.

\section{Discussion}

\subsection{GGTB Basement Structure, Empirical Inferences}

The GGTB northern and the southern boundaries i.e. the Posorja detachment and Tumbes-Zorritos detachment system that evolved coevally during most of the Pleistocene time, exhibit an opposite dipping to the south and to the NNW, respectively. It is suggested that these fault systems are conjugate detachments accommodating the $\sim \mathrm{N}-\mathrm{S}$ trending tensional stress characterizing the GGTB shelf area for the past 1.8 - 1.6 Myr. Both detachments extend 80 to $120 \mathrm{~km}$ at seafloor. For this reason, we assume that they penetrate deep into the brittle continental crust [48], far below the $6-8 \mathrm{~km}$ thick sediment that accumulated at GGTB depocenters. To the south the Tumbes-Zorritos detachment system that migrated 10 $15 \mathrm{~km}$ toward the SSE i.e. landward during the Pleistocene $[4,23]$ exhibits a pervasive tectonic activity at Present. As opposed, the Posorja detachment is not active at Present [24]. During the Quaternary time, the tectonic activity migrated southward from the Posorja detachment (Figure 5) to the high dipping normal faults bounding the northern rim of the Esperanza sub-basin. A pervasive tectonic asymmetry between the northern and the southern border characterizes the GGTB basin at Present. It is suggested that the still active Tumbes-Zorritos detachment system is the master detachment for the conjugate fault system controlling the GGTB evolution during the past 1.8 - $1.6 \mathrm{Myr}$.

The gravity low, underlying the Tumbes-Zorritos and Esperanza sub-basins depocenters, (Figure 8) trends $\sim \mathrm{N} 45^{\circ} \mathrm{E}$. This gravity low follows major tectonic features at depth including the westward prolongation of the Cretaceous ophiolite suture and the associated Interandean depression. Also, the $\sim \mathrm{N} 45^{\circ} \mathrm{E}$ trending gravity low parallels major morphotectonic features including the TumbesZorritos detachment system, the coastline from Cabo Blanco to Machala (Figure 5), and the Amotapes massif divide (Figure 4). The $\sim 75$ - 65 Ma old ophiolite suture is tightly controlling major active-tectonic features and morphologic elements of northwestern Peru at Present. Owing the lack of resolution of structure below $4-5 \mathrm{~s}$ two-way travel time on industrial seismic records $[4,23$, 24], we consider projecting the Tumbes-Zorritos detachment system at depth using a conservative geometry 
of detachments and faults (Figures 12A and 12B). If this working assumption accepted, the Tumbes-Zorritos detachment system appears to branch upward from the restricted strip at which the Cretaceous ophiolite faces the continental basement at depth.

Two basic situations (Figure 2) characterize the relationship between the Cretaceous ophiolite (Western Cordilleras of Colombia and Ecuador) and the South America continental basement (Central Cordillera of Colombia and Real Cordillera of Ecuador). It includes a few kilometers- to tens of kilometers-wide depression bounding the ophiolite from the metamorphic basement, and a flat eastward-verging obduction megathrust separating the ophiolite from the underthrusted continental basement. Projecting these first-order Andean structural features toward the GGTB area substantiates two different pic- tures for the basin basement structure. 1) As suggested by the free-air gravity anomalies the Interandean depression, which bounds the ophiolite from the continental basement could extend seaward (Figure 12A). If so, this depression may adjust the NAB northward drift controlling this way the GGTB sustained subsidence at depocenter and location trough a pure shear mechanism [49]; 2) The Tumbes-Zorritos detachment system could extend at depth along a major flat detachment (Figure 12B). If this assumption accepted, the detachment may follow the route inherited from the Cretaceous obduction magathrust reactivated by tectonic inversion during the past $1.8-1.6$ Myr. This detachment would adjust the NAB northward drift and the associated GGTB sustained subsidence through a simple shear mechanism.

The eastern end of profile SIS-18 (Figure 7) shows the

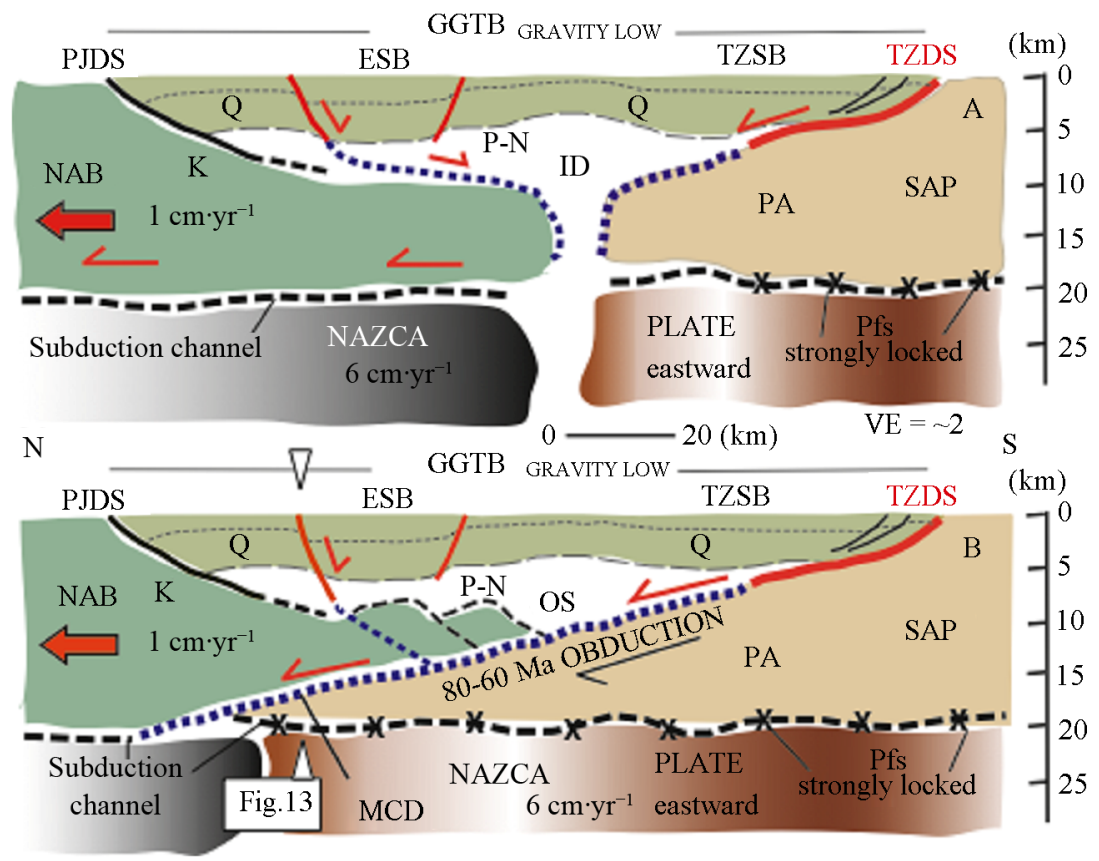

Figure 12. Two possible along-strike tectonic reconstructions of the GGTB area showing the role of deep rooted inherited tectonic features in accommodating the extension originating from the NAB northward drift (solid red arrow), and controlling basin subsidence and location. (A) The extension is accommodated by pure shear mechanism along the Interandean depression (ID). Thick blue dash line shows the possible prolongation of the active Tumbes-Zorritos detachment system (thick red line) at depth; (B) The extension is almost entirely accommodated by simple shear deformation. The Cretaceous ophiolite suture (OS) branches upward to the active Tumbes-Zorritos detachment system. The detachment along the Andean ophiolite suture resulted from tectonic inversion along the $\sim 75$ - 65 Ma old flat underthrusting i.e. obduction of the South America continental basement (PA). A low-angle shear zone (thick blue dash-line + the thick red line showing the Tumbes-Zorritos detachment system) extends to the subduction channel at depth. Both end-member reconstructions (A) and (B) assume that northward prolongation of the South America continental basement (PA of the Amotapes massif) remains strongly locked along the northward prolongation of the Peru flat slab. Northward drift of the NAB originated from plate coupling along the Carnegie ridge segment. See text for more detail. PA-Paleozoic continental basement rock; K-Cretaceous ophiolite; P-N-Paleogene-Neogene sediment; Q-Quaternary sediment. ID-Interandean depression; ESB-Esperanza sub-basin; MCD-MidCrust detachment; NAB-North Andean block; OS-ophiolite suture; Pfs-Peru flat slab; PJDS-Posorja-Jambeli detachment system; SAP-South America plate; TZDS-Tumbes-Zorritos detachment system; TZSB-Tumbes-Zorritos sub-basin; VE-vertical exaggeration. Thick black line-inactive fault at Present; thick red line-active fault at Present; blue dash line-inferred prolongation of fault at depth; thick dash line-major detachment at depth; thin black arrow-obduction; thick red arrowactive detachment and fault. Brown color-Peru flat slab; grey color-Ecuador slab dipping $25^{\circ}-35^{\circ}$. Location on Figure 5; location of Figure 13 is shown. 
GGTB basement exhibiting a mid-crust major reflection dipping gently to the east. It allowed [20] to identify two different basement units $\mathrm{S}$ and $\mathrm{S}$, the last one being the upper one. Owing to the short distance (Figure 5) that separates the SIS-18 profile from the Posorja detachment system and the Santa Elena rise i.e. Cretaceous ophiolite basement, we assume that the Cretaceous ophiolite rock extends southward being the $S^{\prime}$ upper unit i.e. $S^{\prime}$ is equivalent to K, Figure 7. Assuming the assumption proposed at Figure 12B i.e. underthrusting of the Amotapes massif metamorphic basement beneath the Cretaceous ophiolite the $\mathrm{S}$ basement (Figure 7) appears as a possible northward prolongation of the South America continental basement. The Mid-Crust detachment would be that way a northward extension of the Tumbes-Zorritos detachment system. The assumption as proposed at Figure 12A opens no specific origin not only for the mid-crust reflection but also for the so-called $\mathrm{S}$ basement. Added to these deficiencies, the pervasive tectonic asymmetry of the basin at Present (see above), allow us to favor the simple shear model (Figure 12B) for the GGTB evolution. We support the idea that the southern GGTB continental basement i.e. beneath the TumbesZorritos detachment system is significantly extending northward beneath the GGTB area. It is likely that the Peru flat slab extends beneath the southern GGTB area and the plate interface strongly locked along this segment. This situation is likely to facilitate the northward drift of the GGTB northern edge in the NAB tectonic wake and would account for the pervasive seismic gap of this area.

\subsection{Seismic Behavior}

The $700-800 \mathrm{~km}$ seismic gap, first proposed by [6] to extend along the southern Ecuador and northern Peru forearc i.e. from $1^{\circ} \mathrm{N}$ to $8^{\circ} \mathrm{S}$ (Figure 10) is restricted to the GGTB segment between $2^{\circ}$ and $3^{\circ} 30^{\prime} \mathrm{S}$ (see Section 8). Because the $\sim 1000 \mathrm{~km}$ Peru Volcanic gap extends northward to $\sim 2^{\circ} \mathrm{S}$ (to the Sangay volcano, southern Ecuador), it is inferred that the flat slab characterizing the Peru subduction zone over the same segment extends northward along the southern Ecuador Andes, including the GGTB segment. The high coupling at plate interface that induces longer-term recurrence interval between earthquakes could explain that no historic earthquake originating from the subduction megathrust has been recorded along the GGTB segment. However, evidence suggests that lower coupling takes place at the interplate limit beneath the GGTB as compared to the north along the Carnegie ridge subduction segment, and to the south along the over-thickened crust of the Amotapes massif.

Seismogenesis along the subduction channel occurs where the upper plate is coherent and sufficiently thick to store the elastic strain released during earthquakes. From a global examination of subduction zones, it has been suggested $[50,51]$ that block sliver drifting i.e. such as the NAB limits the maximum size of thrust subduction earthquakes at plate interface. The calculated 13.5 - 20 $\mathrm{km}$ of GGTB basin lengthening related to NAB northward drifting [24] matches a $5 \%$ to $10 \%$ of crustal thinning [4]. Additional subduction erosion at depth may result in a greater amount of crustal thinning beneath the GGTB area. Also, the subsidence along the GGTB area tends to weak the crust preventing the capacity to store elastic strain, which in turn favors subduction erosion of the overriding plate. If the overriding plate is not coherent enough to store elastic strain, the capacity of generating earthquake decreases even if the mechanical coupling between the subducting and overriding plates is high. Indeed an increase in tectonic deformation would promote increased fracturing rather than flexing. In other word, the pervasive GGTB seismic gap suggests that part of its sustained subsidence may originate from subduction erosion working at depth. A link between the slip of basin-centered asperities in great subduction zone earthquakes and subduction erosion at depth that controls the subsidence of the overriding basin has been documented [50]. Because no great historical earthquake is documented beneath the GGTB, no basin-centered asperity is documented until Present. Nevertheless, it should be noted that the GGTB developed along the shelf area instead to be located downslope along the deep-sea terrace as typical basin-centered asperity [50]. Based on trench parallel gravity variations [51] predicted low elastic strain accumulation between $1^{\circ} \mathrm{N}$ to $3^{\circ} \mathrm{S}$ and higher elastic strain accumulation from $4^{\circ} \mathrm{S}$ to $8^{\circ} \mathrm{S}$. This observed pattern that excludes the GGTB segment is consistent with differences in interplate coupling along the decollement, and interplate seismic event occurrence. Indeed, a weaker coupling at plate interface induces a lack of seismogenic potential and a low probability for large earthquake occurrence. The negative TPAG (trench-parallel gravity anomaly) identified along northern Peru makes this segment exposed to great earthquakes. As opposed the continental margin segment between $1^{\circ} \mathrm{N}$ and $3^{\circ} \mathrm{S}$ exhibits lower elastic-strain accumulation. However, this particular segment shows a strong segmentation including the Carnegie ridge sub-segment that must be analyzed separately in terms of strain accumulation.

Although the GGTB northern edge is moving northward at a rate of $\sim 1 \mathrm{~cm} \cdot \mathrm{yr}^{-1}$ as regard the southern edge, the basin area exhibits a pervasive seismic gap throughout (Figure 11). Instead of evidencing a locked zone, this low earthquake occurrence may be related to aseismic creeping deformation acting along detachment zones that is in good agreement with low angle fault behavior [52]. The lack of recorded earthquake along gently dipping and active faults suggested that these structures slipped 
aseismically in many places. The elastic stress is at a threshold for failure along the decollement allowing no stress accumulation.

\subsection{Tectonic Evolution, Across-Strike Perspective}

Two tectonic regimes showing different styles and ages controlled the evolution of the southern Ecuador and northern Peru continental margin and shelf. The N-S trending tensional regime confined along the shelf area is $\mathrm{NAB}$ drifting-related while the $\mathrm{E}-\mathrm{W}$ trending tensional regime along the continental margin resulted from tectonic erosion working along the subduction channel at depth. The stress regime rotation occurs along the $5-10$ $\mathrm{km}$ wide Decoupling Strip (Figure 5) bounded to the east and to the west by the Inner and Outer Domito-Banco Peru fault systems (Figure 7), respectively. The shelf area under NAB drift control i.e. the GGTB area is under long-term N-S trending tensional stress, at least for the past 1.8 - $1.6 \mathrm{Myr}$.

At Present time, the GGTB acts as a barrier preventing major detrital sediment input to the trench axis. Although an average $1.7 \mathrm{~mm} \cdot \mathrm{yr}^{-1}$ subsidence rate has been calculated for the past 1.8 - 1.6 Myr sediment input along the GGTB area must be non-steady through time. Indeed, pervasive unconformities that roughly underline the early Upper Pleistocene boundary characterize the upper section of the sediment, which accumulated throughout the GGTB. Because most of the basin extends in water depth shallower than $100 \mathrm{~m}$, it was subject to exposure in relation with sea level drops during low stands of the past four glaciations. When exposure occurred the sediment loading originating from the Andes bypassed the GGTB area allowing the detrital sediment to be transported to the trench axis. It is suggested that the trench axis supply by detrital sediment i.e. trench turbidite occurred during the past glacial lowstands of Middle to Late Pleistocene. Conversely, accumulation of sediment along the GGTB area occurred during highstands as exemplified at Present. Instead to be non-steady through time, detrital sediment with high porosity potential enters the subduction channel since 500 - $600 \mathrm{kyr}$, at least. Assuming a $6-7 \mathrm{~cm} \cdot \mathrm{yr}^{-1}$ convergence rate between the Nazca and South America plates, the underthrust sediment is dragged with the downgoing plate to within $\sim 30$ to $42 \mathrm{~km}$ landward from the trench axis. Quantifying physical properties variations along the first $30 \mathrm{~km}$ of the subduction channel, [32] have identified three zones of transformational changes of underthrust sediment, zones I to III from the trench axis. Main change occurs at zone III (Figure 6) located between 12 and $30 \mathrm{~km}$ landward from the trench axis. Within this zone, porosity falls abruptly indicating sediment compaction, release of over-pressured fluids, elastic deformation of grain to granular cataclasis. The sudden fluid released in zone III has been proposed to induce hydrofracturing favoring basal erosion, and probably installing the adequate conditions for the beginning of earthquake generation at the updip limit i.e. the zone III of the seismogenic zone. Therefore, at distances varying from $\sim 12$ to $25 \mathrm{~km}$ from the trench axis, sudden release of overpressured fluids promotes a landward increase of plate coupling along the subduction channel at depth. The non-steady input of detrital sediment to the trench axis should also induce nonlinear physical properties into underthrust sediment along the subduction channel that in turn may promote across trend variation in the updip limit location, and evolution through time.

Because the EW trending extensional regime of the continental margin extends upslope along the Upper slope (Figure 13A), it is assumed that subduction erosion and higher plate coupling at depth extend $20-55 \mathrm{~km}$ eastward i.e. landward from the updip limit i.e. the so-called zone III (Figure 6). The Decoupling Strip underlines the area at which the extensional tectonic regime is drastically changing from E-W to N-S. The Decoupling Strip, which exhibits $\sim \mathrm{E}-\mathrm{W}$ trending shortening and fluid escape evidences plays a major role in accommodating the drastic change in trend of the extensional stress regime from $\mathrm{E}-\mathrm{W}$ along the continental margin to $\mathrm{N}-\mathrm{S}$ along the shelf area. The Woollard detachment system (Figure 13), which connects the subduction channel at depth, controls the evolution of the continental margin. It allows the Upper slope segment to move eastward relative to the Lower slope wedge considered as fixed. Because the tectonic regime of this continental margin segment remain tensional through time, it is suggested that displacement should be accommodated inboard along the Decoupling Strip, the GGTB area potentially acting as a backstop. To make the eastward displacement possible, the Upper slope segment should remain attached to the Nazca plate at depth as the Lower slope wedge boundaries become unlocked (Figure 13B). Because a pervasive E$\mathrm{W}$ trending tensional stress characterizes the Upper slope segment, it is aimed that subduction erosion is working at depth along the corresponding subduction channel. The Lower slope wedge and the Upper slope segment have asynchronous earthquake cycles, and long recurrence interval between earthquakes. More to the east, along the GGTB area, it is assumed that creeping along the MidCrust detachment (Figure 13) is accommodating the N-S trending drift of the NAB as the subduction channel along the Peru flat slab is strongly locked at depth (Figure 12B).

\section{Conclusions}

The $\sim 75$ - 65 Ma ophiolite suture and Interandean de- 


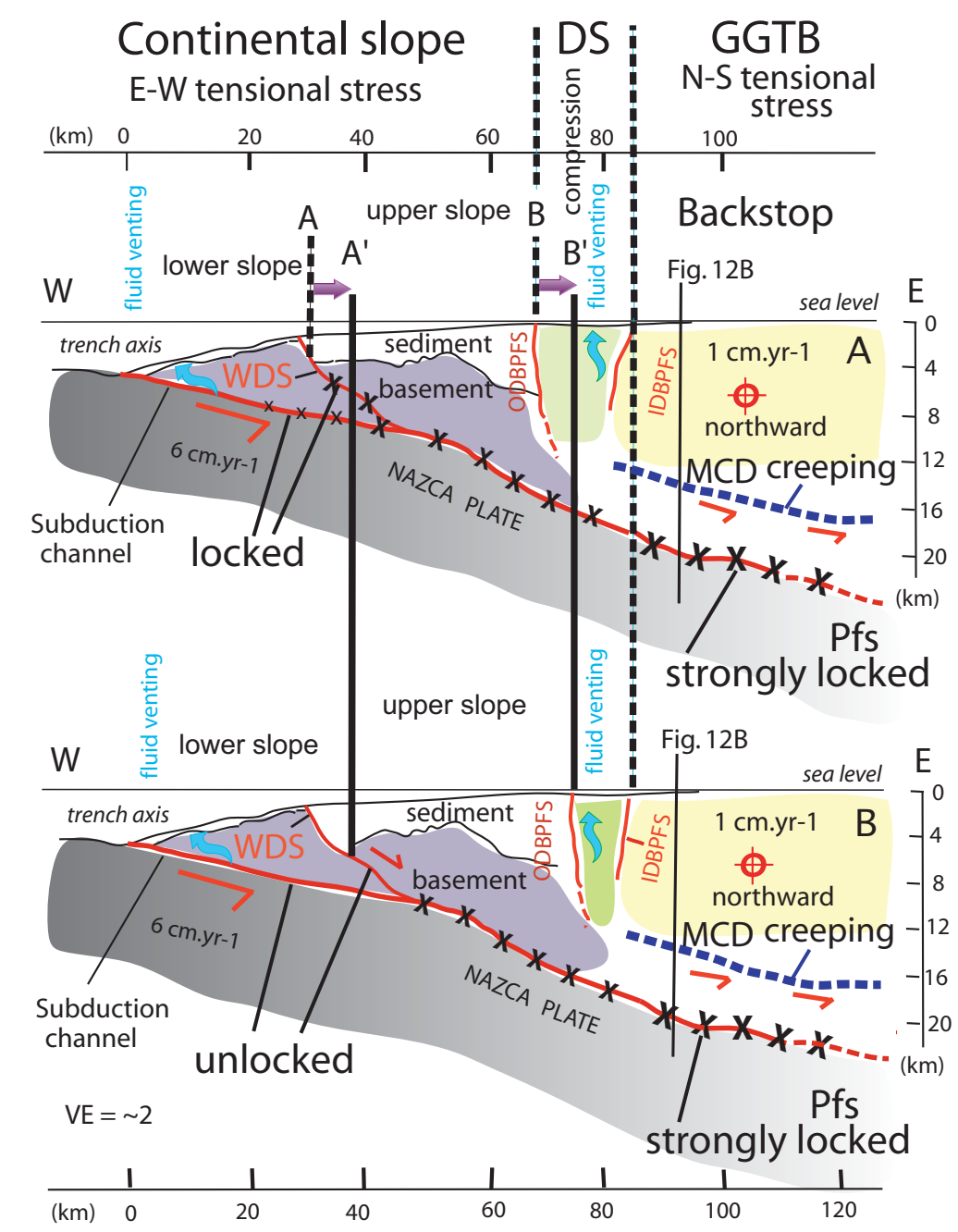

Figure 13. The across-strike tectonic evolution of the GGTB transect, accepting the favored end-member assumption depicted at Figure 12B. (A) Between earthquakes, the seismogenic zone is locked. It extends from the updip limit (shown at Figure 6) to within areas located beneath the GGTB. Because the Peru flat-slab margin is unusually cold the stick-slip seismogenic behavior is accepted to extend landward, beyond the GGTB. The Woollard detachment system is also locked. Creeping along the Mid-Crust detachment (thick blue dash-line) accommodates the NAB northward drift. Note that the so-called Mid-Crust detachment is the main detachment (thick blue dash-line) shown at Figure 12B; (B) During the seismic rupture of the Lower slope segment, the Upper slope segment remains attached to the Nazca plate at depth. It allows the Upper slope segment (AB) to move eastward (A'B') as rupture propagates along the Woollard detachment system. The purple solid arrow shows the landward shift of the Upper slope segment. Compression and associated fluid venting along the Decoupling Strip accommodate the landward displacement, the Inner Domito-Banco Peru fault system remaining fixed as regard the Upper slope landward shift. See text for more detail. DS-Decoupling Strip; IDBPFS-Inner Domito-Banco Peru fault system; MCD-mid-crust detachment; ODBPFS-Outer Domito-Banco Peru fault system; Pfs-Peru flat slab; WDS-Woollard detachment system. Location of profile on Figures 3 and 5.

pression are first order inherited tectonic features, deep seated into the Andean lithosphere. Regional geology and gravimetric anomalies document that these tectonic features of northern ophiolite Andes extend seaward beneath the GGTB depocenters including the Tumbes-Zorritos and Esperanza sub-basins. It is aimed that reactivation of these major tectonic elements into the modern dynamic of the Andes controls the GGTB location and evolution during the past $1.8-1.6 \mathrm{Myr}$, at least. Whether remobilization occurred along the Interandean depression or the ophiolite suture, the GGTB evolved trough pure or simple shear mechanisms, respectively. Because the GGTB exhibits an along strike major asymmetry associated with a pervasive seismic gap, we favor the simple shear solution (Figure 12B).

Subduction-erosion is suspected to be actively working at depth beneath the GGTB area. Since no seismic activity is identified along the subduction channel, no evidence exists to establish a link between subsidence and a basin-centered asperity. Higher coupling at plate 
interface to the north i.e. along the Carnegie ridge segment and to the south Peru flat slab beneath the Amotapes massif and southern GGTB area facilitates the GGTB basement stretching, which in turn sustains the GGTB subsidence.

Three significant points of matter should be considered to disentangle the tricky situation of the Andean forearc along the GGTB segment exhibiting a dramatic tensional strain rotation. 1) The E-W and N-S trending tensional stresses of the continental margin and shelf areas originnated from different and self-sufficient processes, the subduction erosion at depth and the NAB northward drift, respectively. These two different processes operated at different time scale: non-steady through time for subduction erosion along the subduction channel in association with potential earthquake events, continuous through time in association with creeping along the Mid-Crust detachment, respectively; 2) The landward-dipping Woollard detachment system, which connects the subduction channel at depth, controls the evolution of the continental margin. This landward dipping flat fault is proposed to be a major decoupling detachment system between the continental margin basement of the Upper slope and the Lower-slope wedge that may evolve independently. The potential seismogenic zone documented along the subduction channel beneath the Lower slope may evolve independently from the inboard subduction channel located beneath the Upper slope. It allows (Figure 13B) the Upper-slope continental basement to remain attached to the Nazca plate at depth as the Lower slope plate boundary becomes unlocked. Since the E-W trending tensional stress extends along the Upper slope, it is inferred that subduction erosion is extending inboard to beneath the shelf slope break i.e. the Outer Domito-Banco Peru fault system; 3) The Decoupling Strip at the shelf-slope break, and the GGTB Mid-Crust detachment along the shelf area accommodate permanently not only the NAB northward drift but also the landward shifting of the continental margin at depth. The Decoupling Strip and the Woollard detachment system accommodate a significant amount $(3 \%-5 \%$ i.e. 3 $5 \mathrm{~km}$ during the past $1.8-1.6 \mathrm{Myr}$ ) of the convergence between the Nazca and South America plates.

Because the GGTB is a promising site of hydrocarbon resources, to understand processes at the origin of this escape-induced forearc basin has major economic interest. The Sunda strait [53-56], the Golfo de Penas [57,58], and the Bussol strait [59] are forearc basins exhibiting geodynamic similarities with the GGTB.

\section{Acknowledgements}

This study was supported by grants from the Centre National de la Recherche Scientifique (CNRS, France) through the Institut des Sciences de l'Univers (INSU), Research support came also from the Université Pierre et Marie Curie (France), the French Embassy in Quito, the FUNDACYT (Ecuador). PETROECUADOR (Quito and Guayaquil, Ecuador), PETROPERU (Lima, Peru) kindly provided Industrial seismic records and drill data used for this work. In this regard, we are particularly grateful to Marco Rivadeneira, Edgar Riofrio, Marta Ordoñez, Nelson Jimenez, Galo Montenegro, Gerardo Berrones (Ecuador) and Rolando Bolaños, Belizario Cornejo, Oscar Gil (Peru) who contributed most directly to our success. I am grateful to my colleagues Bernardo Beate, Arturo Egüez, Etienne Jaillard, Luis Pilatasig, and many others including students Juan Carlos Lahuathe, Patricio Verdezoto, Wilmer Vaca, and Cesar Witt for creative discussion during a threeyear tenure at the Escuela politécnica Nacional de Quito. Jean-Luc Lamotte is gratefully acknowledged for his assistance in processing the gravimetric data. We have named the major detachment at the Upper slope Lower slope boundary the "Woollard detachment system" in tribute to George P. Woollard who conceived the "Nazca Plate Project" (Georges P. Woollard died in 1979).

\section{REFERENCES}

[1] A. Gansser, "Facts and Theories on the Andes," Journal of the Geological Society London, Vol. 129, No. 2, 1973, pp. 93-131. doi:10.1144/gsigs.129.2.0093

[2] O. Egbue and J. Kellogg, "Pleistocene to Present North Andean 'Escape'," Tectonophysics, Vol. 489, No. 1-4, 2010, pp. 248-257.

[3] J. Bourgois, J.-F. Toussaint, H. Gonzales, J. Azema, B. Calle, A. Desmet, L. A. Murcia, A. P. Acevedo, E. Parra and J. Tournon, "Geological History of the Cretaceous Ophiolitic Complexes of Northwestern South America (Colombia Andes)," Tectonophysics, Vol. 143, No. 4, 1987, pp. 307-327.

[4] C. Witt and J. Bourgois, "Forearc Basin Formation in the Tectonic Wake of a Collision-Driven, Coastwise Migrating Crustal Block: The Example of the North Andean Block and the Extensional Gulf of Guayaquil-Tumbes Basin (Ecuador-Peru Border Area)," Geological Society of America Bulletin, Vol. 122, No. 1-2, 2010, pp. 89-108. doi:10.1130/B26386.1

[5] R. Trenkamp, J. N. Kellogg, T. Freymueller and P. H. Mora, "Wide Plate Margin Deformation, Southern Central America and Northwestern South America, CASA GPS Observations," Journal of South American Earth Sciences, Vol. 15, No. 2, 2002, pp. 157-171.

[6] T. Lay and H. Kanamori, "An Asperity Model of Great Earthquake Sequences, in Earthquake Prediction: An International Review," Maurice Ewing, AGU Washington DC, 1981, pp. 579-592. doi:10.1029/ME004p0579

[7] T. Boinet, J. Bourgois, H. Mendoza and R. Vargas, "Le Poinçon de Pamplona (Colombie): Un Jalon de la Frontière Méridionale de la Plaque Caraïbe," Bulletin de la Societe Geologique de France, Vol. 8, No. 1, 1985, pp. 403-413. 
[8] J. Bourgois, B. Calle, J. Tournon and J. F. Toussaint, "The Andean Ophiolitic Megastructures on the Buga-Buenaventura Transverse (Western Cordillera-Valle, Colombia)," Tectonophysics, Vol. 82, No. 3-4, 1982, pp. 207229.

[9] A. C. Kerr, J. A. Aspen, J. Tarney and L. F. Pilatasig, "The Nature and Provenance of Accreted Oceanic Terranes in Western Ecuador: Geochemical and Tectonic Constraints," Journal of the Geological Society, Vol. 159, No. 5, 2002, pp. 577-594. doi:10.1144/0016-764901-151

[10] J. Bourgois, A. Egüez, J. Butterlin and P. De Wever, “A Synthetic Stratigraphic Model of the Western Cordillera of Ecuador Andes: With Special Reference to the Eocene Apagua Formation," Comptes Rendus de l'Académie des Sciences de Paris, Vol. 311, No. 2, 1990, pp. 173-180.

[11] N. Lebras, F. Mégard, C. Dupuy and J. Dostal, "Geochemistry and Tectonic Setting of Pre-Collision Cretaceous and Paleogene Volcanic Rocks of Ecuador," Geological Society of America Bulletin, Vol. 99, No. 4, 1987, pp. 569-578.

[12] H. Lapierre, D. Bosch, V. Dupuis, V., M. Polvé, R. C. Maury, J. Hernandez, P. Monié, D. Yeghicheyan, E. Jaillard, M. Tardy, B. Mercier de Lépinay, M. Mamberti, A. Desmet, F. Keller and F. Sénebier, "Multiple Plume Events in the Genesis of the Peri-Caribbean Cretaceous Oceanic Plateau Province," Journal of Geophysical Research, Vol. 105, No. B4, 2000, pp. 8403-8421. doi:10.1029/1998JB900091

[13] V. Ramos, "Anatomy and Global Context of the Andes: Main Geologic Features and the Andean Orogenic Cycle," In: S. M. Kay, V. A. Ramos and W. R. Dickinson, Eds., Backbone of the Americas: Shallow Subduction, Plateau Uplift, and Ridge and Terrane Collision, Geological Society of America, Washington DC, 2009, pp. 31-65.

[14] M. Cortés and J. Angelier, "Paleostress Evolution of the Northern Andes (Eastern Cordillera of Colombia): Implications on Plate Kinematics of the South Caribbean Region," Tectonics, Vol. 24, No. 1, 2005, Article ID: TC1008. doi:10.1029/2003TC001551

[15] F. Ego, M. Sebrier, A. Lavenu, H. Yepes and A. Egüez, "Quaternary State of Stress in the Northern Andes and the Restraining Bend Model for the Ecuadorian Andes," Tectonophysics, Vol. 259, No. 1-3, 1996, pp. 101-116.

[16] A. Lavenu, T. Winter and F. Davila, "A Pliocene-Quaternary Compressional Basin in the Interandean Depression, Central Ecuador," Geophysical Journal International, Vol. 121, No. 1, 1995, pp. 279-300.

[17] M. Sosson, J. Bourgois and B. Mercier de Lepinay, "Sea BEAM and Deep-Sea Submersible Nautile Surveys in the Chiclayo Canyon off Peru ( $\left.7^{\circ} \mathrm{S}\right)$. Subsidence and Subduction Erosion of an Andean-type Convergent Margin since Pliocene Time," Marine Geology, Vol. 118, No. 3-4, 1994, pp. 237-256. doi:10.1016/0025-3227(94)90086-8

[18] A. Fildani, A. M. Hessler and S. A. Graham, "Trench-Forearc Interactions Reflected in the Sedimentary Fill of Talara Basin, Northwest Peru," Basin Research, Vol. 20, No. 3, 2008, pp. 305-321. doi:10.1111/j.1365-2117.2007.00346.x

[19] E. Jaillard, M. Ordoñez, S. Benitez, G. Berrones, N. Jimé- nez, G. Montenegro and I. Zambrano, "Basin Development in an Accretionary, Oceanic-Floored Fore-Arc Setting: Southern Coastal Ecuador during Late Cretaceous-Late Eocene Time," In: A. J. Tankart, S. Suarez and H. J. Welsink, Eds., Petroleum Basins of South America, American Association of Petroleum Geologists, AAPG, Tulsa, 1995, pp. 615-631.

[20] A. Calahorrano, "Structure de la Marge du Golfe de Guayaquil (Equateur) et Propriété Physique du Chenal de Subduction, à Partir de Données de Sismique Marine Réflexion et Réfraction," Ph.D. Thesis, Université Pierre et Marie Curie, Paris, 2005, 227 p.

[21] J. Bourgois, G. Pautot, W. Bandy, T. Boinet, P. Chotin, P. Huchon, B. Mercier de Lepinay, F. Monge, J. Monlau, B. Pelletier, M. Sosson and R. von Huene, "Seabeam and Seismic Reflection Imaging of the Tectonic Regime of the Andean Continental Margin off Peru $\left(4^{\circ} \mathrm{S}\right.$ to $\left.10^{\circ} \mathrm{S}\right)$," Earth Planet Science Letters, Vol. 87, No. 1-2, 1988, pp. 111-126.

[22] R. von Huene, J. Bourgois, J. Miller and G. Pautot, “A Large Tsunamogenic Landslide and Debris Flow along the Peru Trench," Journal of Geophysical Research, Vol. 94, No. B2, 1989, pp. 1703-1714. doi:10.1029/JB094iB02p01703

[23] J. Bourgois, F. Bigot-Cormier, D. Bourles, R. Braucher, O. Dauteuil, C. Witt and F. Michaud, "Tectonic Record of Strain Buildup and Abrupt Co-Seismic Stress Release across the Northwestern Peru Coastal Plain, Shelf, and Continental Slope during the Past 200 kyr," Journal of Geophysical Research, Vol. 112, No. B4, 2007, Article ID: B04104.

[24] C. Witt, J. Bourgois, F. Michaud, M. Ordoñez, N. Jimenez and M. Sosson, "Development of the Gulf of Guayaquil (Ecuador) during the Quaternary as an Effect of the North Andean Block Tectonic Escape," Tectonics, Vol. 25, No. 3, 2006, Article ID: TC3017. doi:10.1029/2004TC001723

[25] B. C. Burchfiel and J. H. Stewart, "Pull-Apart Origin of the Central Segment of Death Valley, California," Geological Society of America Bulletin, Vol. 77, No. 4, 1966, pp. 439-442.

[26] P. Mann, M. R. Hempton, D. C. Bradley and K. Burke, "Development of Pull-Apart Basins," Journal of Geology, Vol. 91, No. 5, 1983, pp. 529-554.

[27] J. T. Freymueller, J. Kellogg and V. Vega, "Plate Motions in the North Andean Region," Journal of Geophysical Research, Vol. 98, No. B12, 1993, pp. 21,853-21,863.

[28] J. Bourgois, D. Bourles and R. Braucher, "Reply to Comment by K. Pedoja et al. on Tectonic Record of Strain Buildup and Abrupt Coseismic Stress Release across the Northwestern Peru Coastal Plain, Shelf, and Continental Slope during the Past $200 \mathrm{kyr}$," Journal of Geophysical Research, Vol. 116, No. B9, 2011, Article ID: B09402. doi:10.1029/2011JB008582

[29] J. Bourgois and C. Witt, "Forearc Basin Location Originating from Tectonic Inversion along an Old Ophiolite Suture: The Gulf of Guayaquil-Tumbes Basin (EcuadorPeru Border)," Fall Meeting Supplement, Vol. 89, No. 53, 2008, Abstract T11B-1862. 
[30] G. L. Shepherd and R. Moberly, "Coastal Structure of the Continental Margin Northwest Peru and Southwest Ecuador," In: L. D. Kulm, J. Dymond, E. J. Dasch and D. M. Hussong, Eds., Nazca Plate: Crustal Formation and Andean Convergence, Geological Society of America, Washington DC, 1981, pp. 351-391.

[31] J. Bourgois, Y. Lagabrielle, P. De Wever, E. Suess and NAUTIPERC Team, "Tectonic History of the Northern Peru Convergent Margin during the Past 400 ka," Geology, Vol. 21, No. 6, 1993, pp. 531-534.

[32] A. Calahorrano, V. Sallares, J.-Y. Collot, F. Sage and C. R. Ranero, "Non-Linear Variations of the Physical Properties along the Southern Ecuador Subduction Channel: Results from Depth-Migrated Seismic Data," Earth Planet Science Letters, Vol. 267, No. 3-4, 2008, pp. 453-467.

[33] R. von Huene and D. Scholl, "Observations at Convergent Margins Concerning Sediment Subduction, Subduction Erosion and the Growth of Continental Crust," Reviews of Geophysics, Vol. 29, No. 3, 1991, pp. 279-316. doi:10.1029/91RG00969

[34] D. T. Sandwell and W. H. F. Smith, "Global Marine Gravity from Retracked Geosat and ERS-1 Altimetry: Ridge Segmentation versus Spreading Rate," Journal of Geophysical Research, Vol. 114, No. B1, 2009, Article ID: B01411. doi:10.1029/2008JB006008

[35] J. Bourgois, J. C. Lahuathe, W. Vaca, P. Verdezoto and R. Cornejo, "Mapa Geologico del Ecuador, Hoja de Cañar, Escala 1:50000," Instituto Geografico Militar (IGM), Ministerio de Recursos Naturales y Energeticos (MRNE), Direccion Nacional de Geologia (DINAGE), Quito, 2006.

[36] T. Lay, H. Kanamori and L. Ruff, "The Asperity Model and the Nature of Large Subduction Zone Earthquakes," Earthquake Prediction Research, Vol. 1, No. 1, 1982, pp. 3-71.

[37] J. Swenson and S. Beck, "Historical 1942 Ecuador and 1942 Peru Subduction Earthquakes, and Earthquake Cycles along Colombia, Ecuador and Peru Subduction Segments," Pure and Applied Geophysics, Vol. 146, No. 1, 1996, pp. 67-101.

[38] E. R. Engdahl, R. D. van der Hilst and R. P. Buland, "Global Teleseismic Earthquake Relocation with Improved Travel Times and Procedures for Depth Relocation," Bulletin of the Seismological Society of America, Vol. 88, No. 3, 1998, pp. 722-743.

[39] M. Gutscher, J. Malavieille, S. Lallemand and J. Collot, "Tectonic Segmentation of the North Andean Margin: Impact of the Carnegie Ridge Collision," Earth and Planetary Science Letters, Vol. 168, No. 3-4, 1999, pp. 255270.

[40] B. Guiller, L.-L. Chatelain, E. Jaillard, H. Yepes, G. Poupinet and J.-F. Fels, "Seismological Evidence on the Geometry of the Orogenic System in Central-Northern Ecuador (South America)," Geophysical Research Letters, Vol. 28, No. 19, 2001, pp. 3749-3752.

[41] M. Barazangi and B. Isacks, "Spatial Distribution of Earthquakes and Subduction of the Nazca Plate beneath South America," Geology, Vol. 4, No. 11, 1976, p. 686. doi:10.1130/0091-7613(1976)4<686:SDOEAS >2.0.CO;2

[42] A. Hasegawa and I. S. Sacks, "Subduction of the Nazca
Plate beneath Peru as Determined from Seismic Observations," Journal of Geophysical Research, Vol. 86, No. B6, 1981, pp. 4971-4980.

[43] R. H. Pilger, "Plate Reconstructions, Aseismic Ridges, and Low-Angle Subduction beneath the Andes," Geological Society of America Bulletin, Vol. 92, No.7, 1981, pp. 448-456.

[44] A. M. Pelayo and D. A. Wiens, "The November 20, 1960 Peru Tsunami Earthquake: Source Mechanism of a Slow Event," Geophysical Research Letters, Vol. 17, No. 6, 1990, pp. 661-664. doi:10.1029/GL017i006p00661

[45] J. F. Lander, "Seismological Notes-November and December 1970," Bulletin of the Seismological Society of America, Vol. 61, No. 3, 1971, pp. 1101-1105.

[46] J. Chappell, Y. Ota and K. Berrymann, "Late Quaternary coseismic Uplift History of Huon Peninsula, Papua New Guinea," Quaternary Science Reviews, Vol. 15, No. 1, 1996, pp. 7-22. doi:10.1016/0277-3791(95)00062-3

[47] D. Melnick, B. Bookhagen, M. R. Strecker and H. P. Echtler, "Segmentation of Megathrust Rupture Zones from Fore-Arc Deformation Patterns over Hundreds to Millions Years, Arauco Peninsula, Chile," Journal of Geophysical Research, Vol. 114, No. B01407, 2009. doi:10.1029/2008JB005788

[48] J. A. Jackson, "Active Normal Faulting and Crustal Extension," In: M. P. Coward, J. F. Dewey and P. L. Hancock, Eds., Continental Extensional Tectonics, Vol. 28, Geological Society Special Publications, London, 1987, pp. 3-17.

[49] W. R. Buck, F. Martinez, M. S. Streckler and J. R. Cochran, "Thermal Consequences of Lithospheric Extension: Pure and Simple," Tectonics, Vol. 7, No. 2, 1988, pp. 213-234.

[50] R. E. Wells, R. J. Blakely, Y. Sugiyama, D. W. Scholl and P. A. Dinterman, "Basin-Centered Asperities in Great Subduction Zone Earthquakes: A Link between Slip, Subsidence, and Subduction Erosion?" Journal of Geophysical Research, Vol. 108, No. B10, 2003. doi:10.1029/2002JB002072

[51] T. R. A. Song and M. Simons, "Large Trench-Parallel Gravity Variations Predict Seismogenic Behavior in Subduction Zones," Science, Vol. 301, No. 5633, 2003, pp. 630-633.

[52] B. Wernicke, "Low-Angle Normal Faults and Seismicity: A Review," Journal of Geophysical Research, Vol. 100 No. B10, 1995, pp. 20159-20174. doi:10.1029/95JB01911

[53] P. Huchon and X. Le Pichon, "Sunda Strait and Central Sumatra Fault," Geology, Vol. 12, No. 11, 1984, pp. 668672.

[54] M. Diament, H. Harjono, K. Karta, C. Deplus, D. Dahrin, T. Zen, M. Gerard, O. Lassal, A. Martin and J. Malod, "Mentawai Fault Zone off Sumatra: A New Key to the Geodynamics of Western Indonesia," Geology, Vol. 20, No. 3, 1992, pp. 259-262.

[55] H. Lelgemann, M. A. Gutscher, J. Bialas, E. R. Flueh, W. Weinrebe and C. Reichert, "Tensional Basins in the Western Sunda Strait," Geophysical Research Letters, 
Vol. 27, No. 21, 2000, pp. 3545-3548. doi:10.1029/2000GL011635

[56] H. Kopp, E. R. Flueh, D. Klaeschen, J. Bialas and C. Reichert, "Crustal Structure of the Central Sunda Margin at the Onset of Oblique Subduction," Geophysical Journal International, Vol. 147, No. 2, 2001, pp. 449-474. doi:10.1046/j.0956-540x.2001.01547.x

[57] R. D. Forsythe and E. P. Nelson, "Geological Manifestations of Ridge Collision: Evidence from the Golfo de Penas-Taitao Basin, Southern Chile," Tectonics, Vol. 4, No. 5, 1985, pp. 477-495. doi:10.1029/TC004i005p00477

[58] J. Bourgois, C. Guivel, Y. Lagabrielle, T. Calmus, J. Boulègue and V. Daux, "Glacial-Interglacial Trench Sup- ply Variation, Spreading-Ridge Subduction, and Feedback Controls on the Andean Margin Development at the Chile Triple Junction Area $\left(45^{\circ}-48^{\circ} \mathrm{S}\right)$," Journal of Geophysical Research, Vol. 105, No. B4, 2000, pp. 83558386.

[59] G. Kimura, "Oblique Subduction and Collision: Forearc Tectonics and the Kuril Arc," Geology, Vol. 14, No. 5, 1986, pp. 404-407.

[60] R. J. Arculus, H. Lapierre and E. Jaillard, "Geochemical Window into Subduction and Accretion Processes: Raspas Metamorphic Complex, Ecuador," Geology, Vol. 27, No. 6, 1999, pp. 547-550. 